\title{
A biophysical model of population dynamics of the autotrophic dinoflagellate Gymnodinium breve
}

\author{
Gang Liu, Gerald S. Janowitz*, Daniel Kamykowski
}

Department of Marine, Earth \& Atmospheric Sciences, North Carolina State University, Raleigh, North Carolina 27695-8208, USA

\begin{abstract}
A new model of dinoflagellate diel migratory behavior and population dynamics is presented using the Expanded Eulerian Method (Janowitz \& Kamykowski 1999, Ecol Model 118:237-247) and adapting the concept of metabolism-influenced swimming orientation (Kamykowski \& Yamazaki 1997, Limnol Oceanogr 42:1189-1202; Kamykowski et al. 1998a, in: Anderson et al. [eds] Physiological ecology of harmful algal blooms, Springer-Verlag, Berlin, p. 581-599; Yamazaki \& Kamykowski 2000, Ecol Model 134:59-72). The model is constructed to simulate the observations in a 3 d laboratory mesocosm experiment (Kamykowski et al. 1998b, Mar Ecol Prog Ser 167:105-117; Kamykowski et al. 1998c, J Plankton Res 20:1781-1796) on autotrophic Gymnodinium breve (a red tide dinoflagellate species) under a nutrient-replete condition and in $12 \mathrm{~h}$ light:12 h dark cycle. A hypothesis of the acclimations of the G. breve swimming orientation and speed to the internal biochemical and physiological state and external environmental conditions is proposed. A hypothesis proposed by Kamykowski et al. (1998b) on G. breve reproduction strategy is tested in the model by considering the 2 daughter cells coming from a parent cell to differ in internal biochemical composition. The model simulations are in good agreement with the observations. Consistent with the observations, the model predicts the surface aggregation of a portion of the population during the light period with decreasing surface aggregation intensity over the $3 \mathrm{~d}$ period and approximately uniform vertical distribution of the population through the water column during the dark period as well as the diel convergence and divergence patterns of the mean internal cellular carbon and nitrogen between the surface cells and mid-column cells. As expected, G. breve's internal biochemical and physiological states have a strong influence on its migratory behavior and consequently on its population dynamics. By comparison to a simulation with a reproduction strategy producing 2 identical daughter cells, it is shown that the reproduction strategy producing 2 daughters different in biochemical composition appears to be the one adopted by all or at least a large portion of the G. breve population in the experiment.
\end{abstract}

KEY WORDS: Model $\cdot$ Population dynamics $\cdot$ Dinoflagellate $\cdot$ Behavior

\section{INTRODUCTION}

The dinoflagellate Gymnodinium breve has been the focus of research for decades, especially in recent years, because its intensive red tides in the Gulf of Mexico, particularly on the West Florida Shelf, have dramatic adverse impacts on the ecology, marine environment, and human activities. Available field and laboratory observations suggest that $G$. breve (Odum

\footnotetext{
${ }^{*}$ Corresponding author. E-mail: janowitz@ncsu.edu
}

et al. 1955, Steidinger \& Ingle 1972, Steidinger \& Joyce 1973, Heil 1986, Kamykowski et al. 1998b,c, Steidinger et al. 1998) like other dinoflagellates (Eppley et al. 1968, Harrison 1976, Eppley \& Harrison 1979, Weiler \& Karl 1979, Heaney \& Furness 1980, Cullen \& Horrigan 1981, Heaney \& Eppley 1981, Levandowsky \& Kaneta 1987, MacIntyre et al. 1997) exhibits a diel pattern of vertical migration. The vertical migration capability of G. breve is speculated to contribute to its massive harmful algal blooms under certain biological and physical conditions (e.g. Heil 1986, Kamykowski et al. 1998b). 
In the field, light intensities decrease with depth, and nutrient concentration usually increases with depth. Thus, Gymnodinium breve's observed basic swimming orientation pattern of ascending during the day light period and descending during the dark period indicates a clear survival strategy as related to natural light and nutrient gradients. However, the observations both in situ and in the laboratory have shown much more complex swimming patterns. Under nutrient-replete laboratory conditions (1) G. breve still continuously vertically migrates, aggregating at the surface during the day and dispersing through the water column at night (Heil 1986, Kamykowski et al. 1998b,c); (2) during the light period only a portion of a G. breve population aggregates at the surface, and surface aggregation varies with time and starts to decrease before the onset of the dark period; (3) during the dark period $G$. breve cells disperse through water column approximately uniformly, though not all the cells at the surface during the light period leave the surface; and (4) some cells deep in the water column start to ascend before the light period. Furthermore, a diel oscillation pattern in the internal cellular biochemical composition between the surface population and the population at depth has been displayed under nutrient replete laboratory conditions (Heil 1986, Kamykowski et al. 1998b). In situ (1) maximum concentrations of $G$. breve have been observed at various depths in the water column under bloom conditions (Steidinger \& Ingle 1972); (2) on many occasions, even throughout the light period, there are no high surface concentrations (Odum et al. 1955); and (3) persistent surface maxima have even been observed throughout the dark period during the bloom (Heil 1986).

Many controlling factors, identified for dinoflagellates in general, may be in play (Heil 1986, Kamykowski et al. 1998b), including internal cellular factors, such as endogenous circadian rhythms (Forward \& Davenport 1970, Forward 1974, Chisholm et al. 1984, Heil 1986), cell cycle stage (Kamykowski 1995), biochemical fluxes (Cullen 1985), biochemical synthesis pattern (Kamykowski 1995, Kamykowski et al. 1998b), cell metabolism (Cullen 1985, Cullen et al. 1985, Kamykowski 1995, Kamykowski \& Yamazaki 1997), and population density (Sibley et al. 1974), and external environmental factors, such as gravity, underwater light climate (Eppley et al. 1968, Blasco 1978, Harris et al. 1979, Heaney \& Talling 1980, Heaney \& Eppley 1981, Passow 1991), previous light history (Forward \& Davenport 1968, Forward 1970, 1973), temperature (Kamykowski 1981), salinity (Kamykowski 1981), thermocline and/or pycnocline (Kamykowski \& Zentara 1977, Blasco 1978, Heaney \& Talling 1980, Kamykowski 1981), and nutrient conditions (Holmes et al. 1967, Eppley et al. 1968, Blasco 1978, Harris et al. 1979, Cullen \& Horri- gan 1981, Heaney \& Eppley 1981, Kamykowski 1981, Tyler \& Seliger 1981, Lebert \& Hader 1996, MacIntyre et al. 1997). Many internal and external controlling factors likely still remain unidentified.

The vertical migrating behavior of autotrophic dinoflagellates has also been studied by means of numerical modeling, but such an endeavor has not been conducted to model the migratory behavior of Gymnodinium breve. Most modeling approaches used in these studies are of the Lagrangian type (e.g. Woods \& Onken 1982, Denman \& Gargett 1995, Kamykowski \& Yamazaki 1997), in which individual dinoflagellate cells are tracked to simulate their behaviors and responses to environmental stimuli. In theory, properly implemented Lagrangian and Eulerian models (see below) will yield the same results, though Lagrangian results would have to be converted to a Eulerian form for comparison with the mostly Eulerian data (taken at fixed positions and times). However, for large populations it becomes impracticable to track all cells present. As an alternative, subsets of the entire population as represented by functional groups may be tracked. The number of subsets can still be quite large. We will consider this point at the end of our model description. Eulerian approaches (e.g., Lande \& Lewis 1989) thus far developed are only capable of using the mean cellular properties of cells at any particular spatial location to represent responses of all the cells present. Thus these cells can only act identically according to the mean characteristics, although they may in reality have totally different responses. A field population usually is composed of cells with different biochemical compositions and physiological states and these cells maybe exhibit totally different responses to the same environmental stimuli, depending on many nonlinearly related internal cellular factors. Thus the traditional Eulerian approach is limited in application in modeling realistic dinoflagellate population migratory behavior and population dynamics. However, the Expanded Eulerian Method (EEM) developed by Janowitz \& Kamykowski (1999) eliminates this limitation by increasing the number of independent variables beyond time and position and has the capability of simulating different behaviors of different cells at any particular spatial location. This approach is discussed in detail below.

Some generic Lagrangian metabolism-influenced orientation models have been developed to simulate migratory behavior controlled by internal cellular biochemical and physiological states (Kamykowski \& Yamazaki 1997, Kamykowski et al. 1998a, Yamazaki \& Kamykowski 2000). This concept of metabolisminfluenced orientation can be incorporated to simulate the migratory behavior of Gymnodinium breve. The purpose of this article is to present a new numerical 
model of population migratory behavior and population dynamics, using the EEM approach and adapting the concept of metabolism-influenced swimming orientation (Kamykowski \& Yamazaki 1997, Kamykowski et al. 1998a, Yamazaki \& Kamykowski 2000). The model is constructed to simulate G. breve's migratory pattern, the dynamics of its internal cellular biochemical composition, and the spatial distribution of its populations under a nutrient replete condition, observed by Kamykowski et al. (1998b,c). The influence of internal cellular biochemical and physiological states on swimming behavior and consequently on the photosynthesis and cell reproduction is the focus of our present model. In this article, the characteristics of the temporal variations of a $G$. breve population's distribution and its average internal cellular biochemical distributions in a mesocosm observed in Kamykowski et al.'s $(1998 b, c)$ experiment is presented first. Then, the structure of the model itself is introduced. Finally, the simulation results will be presented and compared with the laboratory observations.

\section{THE LABORATORY EXPERIMENT}

Our model is run to simulate the laboratory experimental observations by Kamykowski et al. (1998b,c) on Gymnodinium breve under a nutrient-replete condition. Because the biological submodels of our model and the associated parameters are constructed and determined particularly for this species according to the observations from this laboratory experiment, the laboratory experiment and its observational results are presented briefly in this section before the introduction of the model itself. This description is a brief version of that given by Kamykowski et al. (1998b,c).

The non-axenic, unialgal stock cultures of Gymnodinium breve Davis (Wilson isolate) were used for the experiment. The experiment was conducted in a $225 \mathrm{l}$, nutrient-replete $\left(150 \mu \mathrm{M} \mathrm{NO}_{3}-\mathrm{N}\right)$ water column $(155 \mathrm{~cm}$ deep) in a temperature-controlled room at $22^{\circ} \mathrm{C}$. The mesocosm column was illuminated from above on a $12 \mathrm{~h}$ light:12 $\mathrm{h}$ dark cycle with $\sim 350 \mu \mathrm{mol}$ quanta $\mathrm{m}^{-2} \mathrm{~s}^{-1}$ PAR (photosynthetically active radiation) reaching the water surface.

The $3 \mathrm{~d}$ experiment started at 06:00 $\mathrm{h}$ (lights-on) on the first day and ended at 06:00 $\mathrm{h}$ on the fourth day. The experiment was conducted on the daughter cells at 2800 cells $\mathrm{ml}^{-1}$ coming from the quantized parent cells, with the whole population dividing every third day and specifically during the night prior to the first experiment day. The cells were approximately uniformly distributed through the water column at the time of cell division. The quantized growth pattern, obtained by repeatedly isolating the subpopulation that aggregated at the surface in early afternoon, provides an opportunity to study cellular biochemistry using bulk chemical analyses (Kamykowski et al. 1998b) and also a good opportunity for numerical simulation.

During the $3 \mathrm{~d}$ experiment, a portion of the column population aggregated at the surface during the light period with the highest surface concentration occurring at noon each day. The strength of the surface aggregation decreased day by day. During the dark period, the column population dispersed approximately evenly through the water column.

The cellular biochemical composition of the cells collected from the surface and the mid-column $(\sim 0.75 \mathrm{~m}$ below the surface) of the $1.5 \mathrm{~m}$ mesocosm showed that the 'quantized population apparently did not similarly synchronize biochemical composition over the light/dark cycle' (Kamykowski et al. 1998b). Mid-column values of internal cellular carbon (carbohydrates and especially lipids) were consistently higher than surface values during the light period and nearly equal during the dark period. Mid-column values of internal cellular nitrogen (measured protein) were consistently higher than surface values during the light period, and there was less consistency in the surface to mid-column values during the 3 dark periods. Cellular concentrations of most constituents increased during the $3 \mathrm{~d}$ period (Kamykowski et al. 1998b).

Kamykowski et al. (1998b) speculated that the oscillatory pattern in biochemical composition was influenced by the diel biosynthetic patterns and the behavioral redistribution of cells in the water column. They also proposed a theory of a parent-daughter relationship to explain the observed behavioral and biochemical patterns (see Kamykowski et al. 1998b for details): the daughter and the parent may have the same or a different internal cellular biochemical composition, and the 2 daughters from a parent may also have the same or a different one. The different behavioral and biosynthetic patterns between different daughters, which initially may be the same or different, may be the reason for the biochemical divergence observed in the experiment.

\section{MODEL DESCRIPTION}

A spatially 1-dimensional (the vertical position), timedependent model of Gymnodinium breve population dynamics is developed here. In this model, the population dynamics are controlled by the migratory behavior and reproduction. Since most laboratory and field measurements are made at fixed points in space, an Eulerian modeling approach for population dynamics yields results which are directly comparable with measurements. The EEM developed by Janowitz \& Kamy- 
kowski (1999) is adapted. In the traditional Eulerian approach, individual cells at a given time at any particular spatial location can be identified only by population mean for any cellular characteristic. In the EEM approach, in addition to the traditional time and space variables, other variables such as the biochemical internal states of a cell are added into the list of independent variables. Thus, at any time at any particular spatial location, the subpopulations of cells with different sets of internal states within the total population can be calculated. As a consequence, in the EEM approach, at any particular spatial location the responses to the same external cues of the cells with the different internal states can be different and the total response of the population is the collective response of the individual cells. Symbols and their definitions of variables used in the model are given in Table 1.

\section{General structure}

In the present model and the original EEM, the basic dependent variable to describe the population is the number of identical cells (i.e., cells having the same internal states) per unit volume, $\underline{C}$, at a spatial position $(x, y, z)$ and at time $(t)$. More precisely, we define

$$
\underline{C}\left(t, X_{1}, Z_{1}, X_{1}, X_{2}, \ldots, X_{L}\right) \mathrm{d} X_{1} \mathrm{~d} X_{2} \ldots, \mathrm{d} X_{L}
$$

as the number of cells per unit volume at $(x, y, z)$ at time $t$ with $X_{i}-\mathrm{d} X_{i} / 2<X_{i}^{\prime} \leq X_{i}+\mathrm{d} X_{i} / 2$, where $X_{i}$ is any internal cellular state to be considered in the model and $L$ is the number of internal states. Thus, at time $t$, the total cell concentration per unit volume of physical space, $\underline{C}_{\mathrm{T}}$, at a particular position $(x, y, z)$ is the sum of all cells of different internal states at that location,

$\underline{C}_{\mathrm{T}}(t, X, Y, z)=\int \ldots \int \underline{C}\left(t, X, Y, Z, X_{1}, X_{2}, \ldots, X_{L}\right) \mathrm{d} X_{1} \mathrm{~d} X_{2} \ldots, \mathrm{d} X_{L}$

An internal cellular state, $X_{i}$, of any particular cell in a population may change with time according to its exposure to the environmental conditions and its internal biochemical and/or physiological processes.

The governing equation for the number of identical cells per unit volume in $x, y, z, X_{1}, \ldots, X_{L}$ space, $\underline{C}$, is

$$
\begin{aligned}
& \frac{\partial \underline{\underline{C}}}{\partial t}+\frac{\partial(u \underline{C})}{\partial x}+\frac{\partial(v \underline{C})}{\partial y}+\frac{\partial\left[\left(w+V_{z}\right) \underline{C}\right]}{\partial z}+\frac{\partial\left(V_{1} \underline{C}\right)}{\partial X_{1}}+\frac{\partial\left(V_{2} \underline{C}\right)}{\partial X_{2}} \\
& +\ldots+\frac{\partial\left(V_{L} \underline{C}\right)}{\partial X_{L}}=+ \text { Gains - Losses }
\end{aligned}
$$

In Eq. (3), $u, v$, and $w$ are the fluid velocity components, $V_{z}$ is the vertical swimming velocity of a dinoflagellate cell and $V_{i}$ is the advection velocity $\left(\mathrm{d} X_{i} / \mathrm{d} t\right)$ of the internal state of a cell, $X_{i}$, i.e., the time rate of change of that state as experienced by a cell. For example, if the entire population had the value of $X_{10}$ at some time and an uptake rate for $X_{1}$ of $\mathrm{d} X_{1} / \mathrm{d} t\left(=V_{1}\right)$, then a small time interval, $\mathrm{d} t$, later the value of this internal variable would be $X_{10}+V_{1} \mathrm{~d} t_{\text {; }}$ the population would have moved, or been advected, along the $X_{1}$ axis with speed $V_{1}$. In the model, $z$ is positive upwards with $z=0$ at the surface. The gain term on the right hand side is the rate of increase or decrease in cell number due to reproduction. Mother cells are lost and daughter cells gained. The loss term is set to zero because no natural mortality or grazing pressure is considered in the model. Here, as we simulate a laboratory experiment, we shall neglect turbulence in the model and set $u, v, w$ to zeros. The submodels used to predict $\mathrm{d} X_{i} / \mathrm{d} t$ and their controlling factors will be described below.

In the model, cells having identical internal states are assumed to respond to the same external cues identically, while the cells having different internal state(s) may respond to the same external cues differently. A behavioral or physiological response of a cell, $R$, can be a function of time $(t)$, cell position $(x, y, z)$, internal cellular states $\left(X_{i,} i=1, \ldots, L\right)$, and external environmental fields $\left(E_{j,} j=1, \ldots, M\right)$ :

$R=f\left(t, X_{1}, z_{1}, X_{1}, X_{2}, \ldots, X_{L}, E_{1}, E_{2}, \ldots, E_{M}\right)=f(t, \vec{X}, \vec{X}, \vec{E})$

In our present model, the swimming behavior, internal carbon metabolism, nitrogen uptake, photoinhibition, sun-shade acclimation, and cell reproduction are the responses (see below for the details). The different responses of a cell may have their own subsets of $\left(X_{i}\right.$ $\left.E_{i}\right)$. An external environmental condition, $E_{j}$, experienced by a cell may vary with time due to both its own temporal change and the cell's motion (fluid motion and swimming) to different spatial locations. The total population response in a unit volume, $R_{\mathrm{T}}$, can be obtained from the individual responses by the integration

$R_{\mathrm{T}}\left(t, X, y, z, E_{1}, E_{2}, \ldots, E_{M}\right)=$

$\int \ldots \int R\left(t, X_{1}, z_{1}, X_{1}, X_{2}, \ldots, X_{L}, E_{1}, E_{2}, \ldots, E_{M}\right) \underline{C}\left(t, x, y, z, X_{1}, X_{2}, \ldots, X_{L}\right)$ $\mathrm{d} X_{1} \mathrm{~d} X_{2} \ldots, \mathrm{d} X_{L}$

To simulate the laboratory mesocosm experiment, here we consider only a 1-dimensional (the vertical position) model and set the water velocity to zero. The governing Eq. (3) becomes

$$
\begin{aligned}
& \frac{\partial \underline{C}}{\partial t}+\frac{\partial\left(V_{z} \underline{C}\right)}{\partial z}+\frac{\partial\left(V_{1} \underline{C}\right)}{\partial X_{1}}+\frac{\partial\left(V_{2} \underline{C}\right)}{\partial X_{2}} \\
& +\ldots+\frac{\partial\left(V_{L} \underline{C}\right)}{\partial X_{L}}=+ \text { Gains(reproduction) }
\end{aligned}
$$

A finite difference scheme is applied to construct our numerical model. Each independent field, $X_{i}$ is discretized into a finite number of intervals $\left(K_{i}\right)$ between its minimum and maximum value. Then, in the discrete approach, at time $t$ the basic dependent variable, i.e., 
Table 1. List of symbols in the model and their definitions. All the biochemical variables and parameters are given on a per cell basis. Note that in the model computation all other time units are converted into seconds. In the third column of the table, the numbers in '[ ]' give the range of the respective variable values

\begin{tabular}{|c|c|c|}
\hline Symbol & Definition & Value in the model \\
\hline a & Constant in the formula for $P_{\mathrm{m}}$ & $46.0 \mu \mathrm{mol}$ quanta $\mathrm{m}^{-2} \mathrm{~s}^{-1}$ \\
\hline$b$ & Constant in the formula for $P_{\mathrm{m}}$ & $17.0 \mu \mathrm{mol}$ quanta $\mathrm{m}^{-2} \mathrm{~s}^{-1}$ \\
\hline$C$ & $\begin{array}{l}\text { Number of cells } \mathrm{m}^{-2} \text { in a discrete 'box' in } x, y, z, X_{1} \\
\ldots, X_{n} \text { space at time } t \text {, i.e., } \underline{C} \text { in discrete fashion }\end{array}$ & Variable, cells m ${ }^{-2}$ box $^{-1}$ \\
\hline$\underline{C}$ & $\begin{array}{l}\text { Number of cells having the same internal states per unit volume in } \\
x, y, z, X_{1}, \ldots, X_{n} \text { space at a spatial position }(x, y, z) \text { and at time } t\end{array}$ & $\begin{array}{l}\text { Variable, cells per unit volume in } \\
\quad x, y, z, X_{1}, \ldots, X_{n} \text { space }\end{array}$ \\
\hline $\mathrm{Cn}$ & Internal cellular carbon $\left(=X_{1}\right)$, not including $C n_{\text {protein }}$ & Variable, $[36,90]$ pmol C cell ${ }^{-1}$ \\
\hline$C n_{\text {div }}$ & Threshold of $\mathrm{Cn}$ for cell reproduction & $85 \mathrm{pmol} \mathrm{C} \mathrm{cell}^{-1}$ ( $90 \%$ of the range) \\
\hline $\mathrm{Cn}_{\text {Full }}$ & Threshold of $C n$ for swimming orientation control & $87.3 \mathrm{pmol} \mathrm{C} \mathrm{cell}^{-1}(95 \%$ of the range) \\
\hline$C n_{\text {High }}$ & Threshold of $\mathrm{Cn}$ for swimming orientation control & $68.4 \mathrm{pmol} \mathrm{C} \mathrm{cell}^{-1}$ ( $60 \%$ of the range) \\
\hline$C n_{\max }$ & Maximum internal cellular carbon & $90.0 \mathrm{pmol} \mathrm{C} \mathrm{cell}^{-1}$ \\
\hline$C n_{\min }$ & Minimum internal cellular carbon & $36.0 \mathrm{pmol} \mathrm{C} \mathrm{cell}^{-1}$ \\
\hline$C n_{\text {photo }}$ & Net photosynthetic carbon & Variable, pmol C cell ${ }^{-1}$ \\
\hline$C n_{\text {protein }}$ & Carbon in cellular protein & Variable, pmol C cell ${ }^{-1}$ \\
\hline & Cell concentration at a particular position $(x, y, z)$ at time $t$ & Variable, cells $\mathrm{m}^{-3}$ \\
\hline$\overline{C h l}$ & Chlorophyll a concentration in the water & Variable, $\mathrm{mg}$ chl a $\mathrm{m}^{-3}$ \\
\hline$\overline{C h l}$ & Average cellular chlorophyll a concentration & $42.5 \mathrm{pg} \mathrm{chl} \mathrm{a} \mathrm{cell}{ }^{-1}$ \\
\hline$D$ & Depth of the model domain & $1.60 \mathrm{~m}$ \\
\hline$D_{i}\left(j_{i}\right)$ & $\begin{array}{l}\text { A cell's normalized displacement along axis } i \text { at } \\
\text { its interval } j_{i} \text { relative to the interval length, } L_{i}\left(j_{i}\right), \text { in } \mathrm{d} t\end{array}$ & Variable, dimensionless \\
\hline$D C_{i}\left(j_{i}\right)$ & $\begin{array}{l}\text { Change in the number of cells in the discrete box associated } \\
\text { with an interval } j \text { on axis } i \text { due to the advection along axis } i\end{array}$ & Variable, the number of cell \\
\hline$d$ & A constant for determining swimming speed & 0.26 , dimensionless \\
\hline $\mathrm{d} t$ & Time interval & 300 and $600 \mathrm{~s}$ (i.e., 5 and $10 \mathrm{~min}$ ) \\
\hline$E_{3}$ & Sun-shade photoacclimation variable $\left(=X_{4}, 13 \mathrm{~d}\right.$ PAR exposure) & Variable, $[0,190] \mu \mathrm{mol}$ quanta $\mathrm{m}^{-2} \mathrm{~s}^{-1}$ \\
\hline$E_{j}$ & External environmental fields & Dependent on field \\
\hline$e k$ & $\begin{array}{l}\text { Chlorophyll a-concentration-dependent total } \\
\text { apparent light attenuation coefficient }\end{array}$ & Variable, $\mathrm{m}^{-1}$ \\
\hline$e k_{0}$ & PAR attenuation coefficient due to water alone & $0.1 \mathrm{~m}^{-1}$ \\
\hline$H_{\mathrm{c}}$ & Cumulative photoinhibition $\left(=X_{3}\right)$ & Variable, $[0,1]$, dimensionless \\
\hline$H_{\mathrm{cSw}}$ & Threshold of $H_{\mathrm{c}}$ for swimming orientation control & 0.8 , dimensionless \\
\hline$H_{\mathrm{i}}$ & Instantaneous inhibition & Variable, $[0,1]$, dimensionless \\
\hline$I$ & PAR (photosynthetically active radiation) intensity & Variable, 0 (night) or 350 (day) $\mu \mathrm{mol}$ quanta $\mathrm{m}^{-2} \mathrm{~s}^{-1}$ \\
\hline$I_{\mathrm{h}}$ & $\begin{array}{l}\text { Sun-shade acclimated PAR threshold for inducing } \\
\text { instantaneous photoinhibition }\end{array}$ & Variable, $\mu$ mol quanta $\mathrm{m}^{-2} \mathrm{~s}^{-1}$ \\
\hline$I_{k}$ & Sun-shade acclimated saturation light intensity & Variable, $\mu$ mol quanta $\mathrm{m}^{-2} \mathrm{~s}^{-1}$ \\
\hline$I_{\max }$ & Maximum PAR intensity at the surface & $350 \mu \mathrm{mol}$ quanta $\mathrm{m}^{-2} \mathrm{~s}^{-1}$ \\
\hline$I_{\text {th }}$ & PAR threshold for swimming orientation control & $17.5 \mu \mathrm{mol}$ quanta $\mathrm{m}^{-2} \mathrm{~s}^{-1}$ \\
\hline$j_{i}$ & Index of the intervals on the axis of variable $X_{i}$ & Index, $\left[1, K_{i}\right]$ \\
\hline$j_{z}$ & Index of the intervals on the depth axis $z$ & Index, $\left[1, K_{z}\right]$ \\
\hline$K_{i}$ & Number of intervals on the axis of variable $X_{i}$ & $40,40,5,5$ for $C n, N, H_{\mathrm{c}} E_{3}$, respectively, dimensionless \\
\hline$K_{z}$ & Number of intervals on the axis of depth $z$ & 8, dimensionless \\
\hline$K_{N}$ & Half-saturation constant & $0.42 \mu \mathrm{M} \mathrm{NO}_{3}-\mathrm{N}$ \\
\hline$K_{\mathrm{q}}$ & Minimum cellular nitrogen quota for protein synthesis to take place & $8.75 \mathrm{pmol} \mathrm{N} \mathrm{cell}^{-1}$ \\
\hline$L^{4}$ & Number of internal states & Dimensionless \\
\hline$L_{i}\left(j_{i}\right)$ & Length of the interval $j$ on the axis of variable $X_{i}$ or $z$ & Dependent on axis and the interval location on the axis \\
\hline$N$ & Internal cellular nitrogen $\left(=X_{2}\right)$ & Variable, $[6.32,23.3] \mathrm{pmol} \mathrm{N}$ cell $^{-1}$ \\
\hline$N_{\text {div }}$ & Threshold of $N$ for cell reproduction & $23.3 \mathrm{pmol} \mathrm{N} \mathrm{cell}^{-1}(100 \%$ of the range $)$ \\
\hline$N_{\mathrm{i}}$ & Cellular internal non-protein nitrogen pool & Variable, $[5,20]$ pmol N cell ${ }^{-1}$ \\
\hline$N_{\mathrm{i}} / N$ & Ratio of the $N_{i}$ and $N$ in a cell & 0.869, dimensionless \\
\hline$N_{\max }$ & Maximum internal nitrogen & $23.30 \mathrm{pmol} \mathrm{N}$ cell $^{-1}$ \\
\hline$N_{\min }$ & Minimum internal nitrogen & $6.32 \mathrm{pmol} \mathrm{N} \mathrm{cell}^{-1}$ \\
\hline$\left[\mathrm{NO}_{3}\right]$ & External nitrate concentration & $150 \mu \mathrm{M} \mathrm{NO}-\mathrm{N}$ \\
\hline$\left[\mathrm{NO}_{3}\right]_{\text {th }}$ & Ambient nitrate concentration threshold for swimming orientation control & $1.26 \mu \mathrm{M} \mathrm{NO}{ }_{3}-\mathrm{N}$ \\
\hline$P_{1}$ & Light-adapted production rate & $0.25 \mathrm{pmol} \mathrm{C} \mathrm{cell}^{-1} \mathrm{~h}^{-1}$ \\
\hline$P_{\mathrm{m}}$ & Sun-shade acclimated maximum photosynthetic rate & Variable, pmol C cell ${ }^{-1} \mathrm{~h}^{-1}$ \\
\hline$P_{\mathrm{ma}}$ & A constant for determining $P_{\mathrm{m}}$ & $0.67 \mathrm{pmol} \mathrm{C} \mathrm{cell}^{-1} \mathrm{~h}^{-1}$ \\
\hline$P_{\mathrm{mb}}$ & A constant for determining $P_{\mathrm{m}}$ & $0.25 \mathrm{pmol} \mathrm{C} \mathrm{cell}^{-1} \mathrm{~h}^{-1}$ \\
\hline$P_{\mathrm{mc}}$ & Maximum increment of diel photosynthesis variation & $3.33 \mathrm{pmol} \mathrm{C} \mathrm{cell}^{-1} \mathrm{~h}^{-1}$ \\
\hline$P_{\mathrm{md}}$ & Dark-adapted photosynthetic rate & Variable, pmol C cell ${ }^{-1} \mathrm{~h}^{-1}$ \\
\hline$R$ & A behavioral or physiological response of a cell to external cues & Dependent on response or behavior \\
\hline$R_{\mathrm{m}}$ & Dark carbon respiration rate & $0.333 \mathrm{pmol} \mathrm{C} \mathrm{cell}^{-1} \mathrm{~h}^{-1}$ \\
\hline$R_{\mathrm{T}}$ & Total population response in a unit volume & Dependent on response or behavior \\
\hline$S_{i}\left(j_{i}\right)$ & Sign of displacement $D_{i}\left(j_{i}\right)$ & +1 or -1 , dimensionless \\
\hline$S_{250}$ & $\begin{array}{l}\text { Asymptotic swimming speed acclimated to a light } \\
\text { intensity of } 250 \mu \mathrm{mol} \text { quanta } \mathrm{m}^{-2} \mathrm{~s}^{-1}\end{array}$ & $1.0 \mathrm{~m} \mathrm{~h}^{-1}\left(=278 \mu \mathrm{m} \mathrm{s}^{-1}\right)$ \\
\hline$S_{\text {accli }}$ & Light-acclimated maximum swimming speed & Variable, $\mathrm{m} \mathrm{h}^{-1}$ \\
\hline$S C$ & Scale factor for $E_{3}$ & 1.85, dimensionless \\
\hline$T_{3}$ & Time scale of sun-shade acclimated parameters & $3 \mathrm{~d}$ \\
\hline$T_{\text {div }}$ & Cell division time scale & $3 \mathrm{~d} / \mathrm{div}$ \\
\hline$t$ & Time & Variable, s \\
\hline$t_{\mathrm{d}}$ & Length of the daylight period & $12 \mathrm{~h}$ \\
\hline$u$ & Fluid velocity component in $x$ coordinate & Variable, $\mathrm{m} \mathrm{h}^{-1}$ \\
\hline$V_{i}\left(j_{i}\right)$ & Advective velocity of a cell along axis $i$ at the interval $j$ of the axis & Dependent on axis \\
\hline$V_{\max }$ & Maximum nitrate uptake rate & Dependent on internal nitrogen content, pmol $\mathrm{N}_{\text {cell }}{ }^{-1} \mathrm{~h}^{-1}$ \\
\hline$v$ & Fluid velocity component in $y$ coordinate & Variable, $\mathrm{m} \mathrm{h}^{-1}$ \\
\hline$V_{z}$ & Swimming velocity & Variable, $\mathrm{m} \mathrm{h}^{-1}$ \\
\hline$w$ & Fluid velocity component in $z$ coordinate & Variable, $\mathrm{m} \mathrm{h}^{-1}$ \\
\hline$X_{i}$ & Any internal cellular state & Dependent on state \\
\hline$x$ & A horizontal coordinate & Variable, m \\
\hline$y$ & Horizontal coordinate orthogonal to $x$ & Variable, m \\
\hline$z$ & Vertical coordinate, which is zero at the surface and positive upwards & Variable, m \\
\hline$Z T_{i}$ & Depth of the upper boundaries of the $3 \mathrm{~d}$ PAR exposure reference layers & $0,0.32,0.64,0.96 .1 .28 \mathrm{~m}$, and $\infty$ \\
\hline$\alpha$ & Initial slope of the curve of light acclimated swimming speed increment & $0.55 \mu \mathrm{m} \mathrm{m} \mathrm{m}^{2} \mu \mathrm{mol}$ quanta $^{-1}$ \\
\hline$\Gamma$ & Time scale of induction and recovery of the photoinhibition & $1.0 \mathrm{~h}$ \\
\hline$\phi$ & Phase making the maximum value occur at local noon & $0 \mathrm{~h}$ \\
\hline
\end{tabular}


the number of the identical cells per unit volume at a spatial location $(\underline{C})$ in the governing Eq. (6) is replaced by the number of cells per unit horizontal area $(C)$ in a multi-dimensional 'box', a small region of $z, X_{1}, \ldots, X_{L}$ space, constructed by the corresponding intervals of all the independent variables, including the depth,

$$
C(\vec{J})=C\left(j_{z}, j_{1}, j_{2}, \ldots, j_{1}, \ldots, j_{L}\right)=\underline{C} \mathrm{~d} z \mathrm{~d} X_{1} \mathrm{~d} X_{2} \ldots, \mathrm{d} X_{L}
$$

Here, $i$ is the index of axes (i.e., the independent variables), $j_{i}$ is the index of interval on axis $i$, and $j_{z}$ is the index of interval on the depth axis $(z)$. The cells in a box are assumed to be distributed uniformly in each box and have the values of both the internal states and external conditions as the values at the center of the box. This means that the mid-point of each interval is the location of a grid point. Then, the advective velocity along axis $i$ of a cell at the $j$ th interval of the axis $\left(j_{i}\right)$ is the function of its internal states and external conditions at the corresponding grid point and is denoted as

$$
V_{i}\left(\vec{J}, \vec{E}, j_{i}\right) \quad i=z, 1,2, \ldots, L
$$

and is abbreviated as $V_{i}\left(j_{i}\right)$ below. The advective velocities must be specified and calculated before computing the cell redistribution along the corresponding axes at the next time step. The submodels for each internal state and its advective velocity are described below. Once the advective velocity of a cell at an interval of an axis, $j_{i}$, is determined, the displacement, $D_{i}\left(j_{i}\right)$, of the cell in the corresponding box relative to the corresponding width, $L_{i}\left(j_{i}\right)$, of the box in a time interval $\mathrm{d} t$ is calculated by

$D_{i}\left(j_{i}\right)=V_{i}\left(j_{i}\right) \mathrm{d} t / L_{i}\left(j_{i}\right) \quad j_{i}=1,2, \ldots, K_{i} ; \quad i=z, 1,2, \ldots, L$

The total number of intervals, $K_{i}$, and interval lengths can vary between axes, and the different intervals of an axis can be different. The change in cell number in the $j_{i}$ th interval of the $X_{i}$ axis due to advection, $D C_{i}\left(j_{i}\right)$, in time interval $\mathrm{d} t$ is

$$
\begin{aligned}
D C_{i}\left(j_{i}\right)=- & -S_{i}\left(j_{i}\right) \cdot D_{i}\left(j_{i}\right) \cdot C_{i}\left(j_{i}\right)+0.5 \cdot\left[S_{i}\left(j_{i}-1\right)+1\right] \cdot \\
& D_{i}\left(j_{i}-1\right) \cdot C_{i}\left(j_{i}-1\right)+0.5 \cdot\left[S_{i}\left(j_{i}+1\right)-1\right] \cdot \\
& D_{i}\left(j_{i}+1\right) \cdot C_{i}\left(j_{i}+1\right) \quad 1<j_{i}<K_{i} \\
D C_{i}(1)=- & -0.5 \cdot\left[S_{i}(1)+1\right] \cdot D_{i}(1) \cdot C_{i}(1)+0.5 \cdot \\
& {\left[S_{i}(2)-1\right] \cdot D_{i}(2) \cdot C_{i}(2) } \\
D C_{i}\left(K_{i}\right)= & -0.5 \cdot\left[S_{i}\left(K_{i}\right)-1\right] \cdot D_{i}\left(K_{i}\right) \cdot C_{i}\left(K_{i}\right)+0.5 . \\
& {\left[S_{i}\left(K_{i}-1\right)+1\right] \cdot D S_{i}\left(K_{i}-1\right) \cdot C_{i}\left(K_{i}-1\right) }
\end{aligned}
$$

$S_{i}\left(j_{i}\right)$ in the equations is the sign of the displacement $D_{i}\left(j_{i}\right)$, either +1 or -1 . This numerical scheme is equivalent to the 'upwind' differencing, which is numerically stable. Eq. (10) is slightly more complex than the standard upwind differencing form as it allows for either positive or negative speeds. Any intention of the cells in the highest or the lowest interval of any axis to move across the upper or lower boundary of the model domain is forbidden, and these cells are retained in the corresponding interval until the advective direction changes. Thus, at time $t+\mathrm{d} t$, the net change in cell number in a box is the summation of the advective changes related to that box along all the axes,

$$
\begin{gathered}
C\left(t+\mathrm{d} t, j_{z}, j_{1}, \ldots, j_{i}, \ldots, j_{L}\right)=C\left(t, j_{z}, j_{1}, \ldots, j_{i}, \ldots, j_{L}\right)+\left[D C_{z}\left(j_{z}\right)+\right. \\
\left.D C_{1}\left(j_{1}\right)+\ldots+D C_{i}\left(j_{i}\right)+\ldots+D C_{L}\left(j_{L}\right)\right]
\end{gathered}
$$

We note that to satisfy the Courant-Friedrichs-Levy (CFL) criterion for upwind differencing, $\mathrm{d} t$ must be small enough so that the sum of the magnitudes of the displacements is less than 1.

Finally, adding the increase in cell number generated by reproduction into the boxes receiving the fresh daughter cells and subtracting the number of the mother cells from the corresponding reproducing 'boxes', the final updated cell number in a box at time $t+\mathrm{d} t$ is obtained, and the cell concentration in the box is calculated by normalizing the box spatial volume to unit spatial volume. We note that in Janowitz \& Kamykowski (1999) reproduction was not considered and the 2 internal variables used were exposures to the external nitrate and PAR fields over a $1 \mathrm{~d}$ time scale. These 2 variables were taken as proxies for the internal carbon and nitrogen pools. Here we shall eliminate the proxy status for carbon and nitrogen.

\section{Submodels for cellular biochemical and physiological states}

In the Kamykowski et al. (1998b) experiment which we simulate here, the only gradient present in the external conditions is that due to the light intensity decreasing with depth, as the nutrient concentration will be taken as uniform. The observed complexity in the characteristics of the population distribution and especially of the biochemical divergence and convergence between the surface cells and the mid-column cells is impossible to explain by a diel migratory behavior controlled only by phototaxis and geotaxis. A dinoflagellate cell's internal biochemical and physiological states are thus hypothesized to control its migratory behavior (Kamykowski \& Yamazaki 1997, Kamykowski et al. 1998a), growth, and reproduction. Based on the laboratory observations on the relationship between Gymnodinium breve's vertical distribution of internal cellular biochemical composition and population density (Kamykowski et al. 1998b), the model uses the metabolisms of the internal cellular carbon $\left(X_{1}\right.$, not including the carbon in the cellular protein) and nitrogen $\left(X_{2}\right)$, the extent of cumulative photoinhibition $\left(X_{3}\right)$, and the cellular sun-shade acclimation state $\left(X_{4}\right)$ as the controlling factors and as the independent variables 
which determine a cell's swimming behavior, growth, and reproduction. The internal cellular carbon and nitrogen contents are 2 primary and important cellular biochemical constituents. The extent of the cumulative photoinhibition and the cellular sun-shade acclimation state are 2 important physiological conditions determining a cell's capability and efficiency in using solar energy in photosynthetic processes and thus growth.

We consider first the external fields. The value of PAR at the surface, $I(0, t)$, is taken as specified. In our simulation we will take this surface value as a constant during the light period and zero during the dark period. The vertical attenuation of PAR is given by

$$
I(z, t)=I(0, t) \cdot \exp \left(-\int_{z}^{0} e k(z, t) \mathrm{d} z\right)
$$

Here $I(z, t)$ is the PAR at depth $z$ (positive upwards with $z=0$ at the surface). To incorporate the self-shading effect in our model, the chlorophyll a-concentrationdependent total apparent light attenuation coefficient, $e k(z, t)$, given by Riley (1956) is used to calculate the light attenuation coefficient,

$$
e k(z, t)=e k_{0}+0.054 \operatorname{Chl}(z, t)^{2 / 3}+0.0088 C h l(z, t)
$$

where $e k_{0}$ is the PAR attenuation coefficient due to water alone, typically 0.04 to $0.40 \mathrm{~m}^{-1}$. A value of $0.1 \mathrm{~m}^{-1}$ is used in our model. $C h l(z, t)$ is the chlorophyll

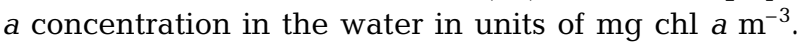
From the observations by Kamykowski et al. (1998b), the range of cellular chlorophyll $a$ in a cell is from 20.0 through $65.0 \mathrm{pg} \mathrm{chl} \mathrm{a} \mathrm{cell}{ }^{-1}$. For the purpose of convenience and reducing the number of independent variables, in our model a constant average cellular chlorophyll a content, $\overline{C h l}$, of $42.5 \mathrm{pg} \mathrm{chl} \mathrm{a} \mathrm{cell}{ }^{-1}$ is used for calculating $C h l(z, t)$ from cell concentration in the water column. A Gymnodinium breve cell concentration between $10^{4}$ and $10^{5}$ cells $\mathrm{l}^{-1}$ can bring the second term in Eq. (13) to the order of $0.1 \mathrm{~m}^{-1}$, and a 1 order of magnitude higher $G$. breve concentration, i.e., between $10^{5}$ and $10^{6}$ cells $1^{-1}$, can also bring the third term in the formula to the same order. These cell concentrations are within the range of the $G$. breve red tide cell concentration. The external nitrate field, $\left[\mathrm{NO}_{3}\right]$, can be taken to be a specified function of depth and possibly time, though in our present simulation we will take it to be a constant, independent of both.

The first internal variable we shall discuss, though perhaps fourth in overall importance, is the $3 \mathrm{~d}$ PAR exposure of a cell, $E_{3}$, i.e., a cell's sun-shade photoacclimation, which will be taken to determine the cell's sun-shade acclimated parameters, including maximum photosynthetic rate, saturation light intensity, and PAR threshold for instantaneous photoinhibition induction. The exposure of a cell to the PAR on a decay time scale of $3 \mathrm{~d}\left(T_{3}=3 \mathrm{~d}\right), E_{3}\left(=X_{4}\right)$, is used as the cellular sun- shade acclimation state, based on Kamykowski \& Yamazaki (1997). The deterministic equation of the $3 \mathrm{~d}$ PAR exposure for a cell is

$$
V_{4}=\frac{\mathrm{d} E_{3}}{\mathrm{~d} t}=\frac{I-E_{3}}{T_{3}}
$$

The range of the $3 \mathrm{~d}$ PAR exposure is between 0 and $I_{\text {max }} / S C$. $S C$ is the scale factor for $E_{3}$. For a periodic, sinusoidally time-dependent PAR,

$$
I(0, t)=I_{\max } \sin \left[(t+\phi) \pi / t_{d}\right]
$$

With all negative values of $I(0, t)$ set to zero, the value of $S C$ can be calculated by inserting Eq. (15) into Eq. (14), then dividing both sides of the resulting equation by the maximum PAR intensity, $I_{\text {max }}$, requiring that the value at $t=1$ day equals the value at $t=0$, and noting the maximum value of $E_{3}$ (Janowitz \& Kamykowski 1999). The same method also applies to periodic PAR with constant intensity during the light period. In this latter case, $S C$ will be 1.85 , or the maximum unscaled value of $E_{3}$ is $0.54 I(0)$. A cell which remains at its initial depth and doesn't swim will have at most an $8 \%$ change in $E_{3}$ in the course of a day, while a cell which swims from the bottom to the top of the simulated mesocosm and remains there for $3 \mathrm{~d}$ will have a change of $60 \%$ of the full range. Neither of these swimming behaviors will be realized in our simulation, and in a $3 \mathrm{~d}$ simulation the change in the value for $E_{3}$ for a cell will be a small fraction of the total range.

The scaled $3 \mathrm{~d}$ PAR exposure variable ranges from zero through 1, while PAR decreases (roughly) exponentially with depth. If $N$ uniform intervals are chosen for the $3 \mathrm{~d}$ PAR exposure variable, all cells below a depth of $\ln N / e k$ would be taken to have the lowest value of this variable. To improve resolution of the domain we choose $N$ non-uniformly spaced contiguous intervals. The water column depth is taken to be split into N 3 d PAR exposure reference layers (note that the definition of these layers is different from the definition of the vertical position $z$, which discretizes the water column), with the initial cell amount distributed uniformly with depth yielding a uniform value of $e k_{1} e k_{\mathrm{u}}$. The scaled $3 \mathrm{~d}$ PAR exposure variable is given the value of 1.0 at the top of the Nth layer $(z=0)$ and a value of zero at the bottom of the lowest layer. The $3 \mathrm{~d}$ PAR exposure values at the top of layers 1 through $N-1$ are then $\exp \left(-e k \times Z T_{i}\right)$, where $i=1, \ldots, N-1$, and $Z T_{i}=[1-(i / N)] \times$ depth. These values along with zero and 1 define the boundaries of each interval, with the mid-point value taken as the average of the values at the top and bottom of each of the $N$ layers. This approach gives equal weight to the variable through the vertical domain.

The second internal state we shall discuss, the cumulative photoinhibition, $H_{\mathrm{c}}\left(=X_{3}\right)$, is a measure of the 
recent (previous few hours) PAR exposure for a cell, or more precisely how much this exposure has exceeded or lagged its $E_{3}$ value. The photoinhibition model is the same as the model used by Janowitz \& Kamykowski (1991) except that the different time scales, $\Gamma$, of induction and recovery can be used. The governing equation for the cumulative photoinhibition, $H_{\mathrm{c}}\left(=X_{3}\right)$, is

$$
V_{3}=\frac{\mathrm{d} H_{\mathrm{C}}}{\mathrm{d} t}=\frac{H_{\mathrm{i}}-H_{\mathrm{C}}}{\Gamma}
$$

The time scales, $\Gamma$, for induction $\left(\mathrm{d} H_{\mathrm{c}} / \mathrm{d} t>0\right)$ and recovery $\left(\mathrm{d} H_{\mathrm{c}} / \mathrm{d} t<0\right)$ of photoinhibition may be different. The instantaneous inhibition, $H_{\mathrm{i}}$, at time $t$, is given by

$$
\begin{array}{ll}
H_{\mathrm{i}}=0 & I<I_{\mathrm{h}} \\
H_{\mathrm{i}}=1.0-\exp \left\{-\left[\left(I-I_{\mathrm{h}}\right) / I_{\mathrm{h}}\right]^{2}\right\} & I \geq I_{\mathrm{h}}
\end{array}
$$

Instantaneous photoinhibition is induced only when instantaneous PAR experienced by a cell exceeds its sun-shade acclimated PAR threshold for instantaneous photoinhibition induction, $I_{\mathrm{h}}$. The ranges of $H_{\mathrm{c}}$ and $H_{\mathrm{i}}$ are both $[0,1]$. We shall take

$$
I_{\mathrm{h}}=2 E_{3}+5
$$

If a cell does not swim, it will be essentially uninhibited; the maximum value of photoinhibition for this cell is 0.003 out of 1.0. Cells which swim upwards can reach values of the photoinhibition of nearly 1.0 in a few hours.

The third internal state we will utilize is carbon (less that involved in protein synthesis). The time-dependent photosynthesis submodel is adopted from Kamykowski \& Yamazaki (1997). The model incorporates 3 different time scales of photosynthetic response to the timedependent irradiation, including the photoinhibition on the time scale of few hours, the diel endogenous circadian rhythm corresponding to the diel variation of the irradiation on the time scale of several hours, and the sun-shade photoacclimation on the time scale of few days. The equation for the net photosynthesis of a phytoplankton cell is taken from Denman \& Marra (1986) for light-adapted photosynthetic rate,

$$
\frac{\mathrm{d} C n_{\text {photo }}}{\mathrm{d} t}=\left[P_{\mathrm{md}}+H_{\mathrm{c}}\left(P_{1}-P_{\mathrm{md}}\right)\right]\left[1.0-\exp \left(-\frac{I}{I_{k}}\right)\right]
$$

where $C n_{\text {photo }}$ is the internal cellular carbon produced by the net photosynthesis, $P_{\mathrm{md}}$ and $P_{1}$ are the dark- and light-adapted production rate per cell, respectively; $I$ is the PAR, which is a function of time and depth; $I_{k}$ is the sun-shade acclimated saturation light intensity; $H_{\mathrm{c}}$ is the cumulative photoinhibition, ranging from zero through unity.

The formula to determine $P_{\mathrm{md}}$ is adapted from Kamykowski \& Yamazaki (1997) to include the diel endogenous circadian variation by making the instantaneous maximum photosynthetic rate $\left(P_{\mathrm{md}}\right)$ a function of the sun-shade acclimated maximum photosynthetic rate $\left(P_{\mathrm{m}}\right)$ increased by a sine-based, time-of-day variable that gives the highest value at local noon with the maximum increment $P_{\mathrm{mc}}$

$$
P_{\mathrm{md}}=P_{\mathrm{m}}+P_{\mathrm{mc}}\left\{\sin \left[(t+\phi) \pi / t_{\mathrm{d}}\right]\right\}^{3}
$$

In the formula, $t_{\mathrm{d}}$ is the length of the day and $\phi$ is the phase making the maximum value occur at local noon. The determination of $P_{\mathrm{m}}, H_{\mathrm{c}}$ and $I_{\mathrm{k}}$ and specification of the constants, $P_{\mathrm{mc}}$ and $P_{1}$, are given below.

Based on Kamykowski \& Yamazaki's (1997) determination method using the $3 \mathrm{~d}$ running average, a new formula is constructed here to determine $P_{\mathrm{m}}$,

$$
P_{\mathrm{m}}=P_{\mathrm{ma}}+P_{\mathrm{mb}} \tanh \left[\left(E_{3}-a\right) / b\right]
$$

where $P_{\mathrm{ma}} P_{\mathrm{mb}}$, $a$ and $b$ are the constants to be determined.

A numerical experiment was conducted to determine the constants in Eqs. (16) \& (20)-(22) for the Gymnodinium breve photosynthetic rate, using the data from the experiment by Kirkpatrick et al. (1997) and the experiment by Shanley \& Vargo (1993). Although these experimental data were obtained for lowlight adapted (60 $\mu \mathrm{mol}$ quanta $\left.\mathrm{m}^{-2} \mathrm{~s}^{-1}\right)$ G. breve cells under a low-light experimental condition (maximum PAR of about $270 \mu \mathrm{mol}$ quanta $\mathrm{m}^{-2} \mathrm{~s}^{-1}$ ), these data are the only available time series of photosynthetic rate for G. breve. The constants determined from these data sets will be extrapolated for the high light regime in our model until further observations become available. To best match the simulated photosynthetic rate with these observed rates, the constants were determined as follow: 0.25 pmol C cell ${ }^{-1} \mathrm{~h}^{-1}$ for $P_{1 ;} 0.67 \mathrm{pmol} \mathrm{C}$ cell $^{-1} \mathrm{~h}^{-1}$ for $P_{\mathrm{ma}} 0.25 \mathrm{pmol} \mathrm{C}$ cell $^{-1} \mathrm{~h}^{-1}$ for $P_{\mathrm{mb}}$ 3.33 pmol C cell ${ }^{-1} \mathrm{~h}^{-1}$ for $P_{\mathrm{mci}} 46.0 \mu \mathrm{mol}$ quanta $\mathrm{m}^{-2} \mathrm{~s}^{-1}$ for $a ; 17.0 \mu \mathrm{mol}$ quanta $\mathrm{m}^{-2} \mathrm{~s}^{-1}$ for $b ; \Gamma$ of $1.0 \mathrm{~h}$ for both the induction and recovery; and

$$
I_{k}=E_{3}
$$

Finally, the governing equation for the internal cellular carbon, $C n\left(=X_{1}\right)$, not including the carbon in the cellular protein, is given during the light period by

$$
V_{1}=\frac{\mathrm{d} C n}{\mathrm{~d} t}=\frac{\mathrm{d} C n_{\text {photo }}}{\mathrm{d} t}-\frac{\mathrm{d} C n_{\text {protein }}}{\mathrm{d} t}
$$

and during the dark period by

$$
V_{1}=\frac{\mathrm{d} C n}{\mathrm{~d} t}=-R_{\mathrm{m}}-\frac{\mathrm{d} C n_{\text {protein }}}{\mathrm{d} t}
$$

where $R_{\mathrm{m}}$ is the dark respiration rate of cellular carbon only in effect during the dark period and $C n_{\text {protein }}$ is the internal cellular carbon built into the cellular protein. The constant value of $R_{\mathrm{m}}$ is chosen as $0.333 \mathrm{pmol} \mathrm{C}$ cell $^{-1} \mathrm{~h}^{-1}$ (Shanley \& Vargo 1993). Again, this value was obtained for low-light adapted Gymnodinium 
breve cells under a low-light experimental condition with no data available for a high-light regime. In our model, once the protein is built, it, with the associated carbon, always remains as protein in a cell and is not lost out of the cell. Hence, the respiration does not apply to the carbon in the protein and it is excluded from $\mathrm{Cn}$ (loss of protein and the carbon in the protein could be accommodated by a higher uptake rate, but was an unnecessary complication with no supporting data available). The range of the cellular carbon in our model is between the minimum $36.0\left(C n_{\min }\right)$ and the maximum $90.0\left(C n_{\max }\right)$ pmol C cell ${ }^{-1}$ (Heil 1986). An estimate of the cost of motility to a dinoflagellate cell in terms of the total cell energy budget is less than $5 \%$ (Raven 1983), so it is neglected in our model. The expression for $\mathrm{d} C_{\text {protein }} / \mathrm{d} t$ is discussed below following the discussion on nitrate uptake.

The final internal variable is the total nitrogen content of a cell. Assuming that the only external nitrogen resource is nitrate and that there is no nitrogen loss from the cell (again, loss of protein and the carbon in the protein could be accommodated by a higher uptake rate, but was an unnecessary complication with no supporting data available), the governing equation for the internal cellular nitrogen, $N\left(=X_{2}\right)$, is the Michaelis-Menten equation of nitrogen uptake,

$$
V_{2}=\frac{\mathrm{d} N}{\mathrm{~d} t}=V_{\max } \frac{\left[N O_{3}(z)\right]}{K_{N}+\left[N O_{3}(z)\right]}
$$

Here, the half-saturation constant, $K_{N}$ of $0.42 \mu \mathrm{M} \mathrm{N}$ (Steidinger et al. 1998) is used; $\left[\mathrm{NO}_{3}(z)\right]$ is the external nitrate concentration and can vary with depth, $z$. In this laboratory-based simulation, this depth variation of nitrate is not involved, but the capability is modeled for future application of the model to field situations (Liu 2000).

The range of the internal nitrogen pool of a cell not measured as protein, $N_{\mathrm{i}}$, is approximately between $5\left(N_{\mathrm{i} \text { min }}\right)$ and 20.0 pmol $\mathrm{N}$ cell $^{-1}\left(N_{\mathrm{i} \max }\right)$ based on preliminary data collected by D.K. and the range of its nitrogen-in-measured-protein is between 1.32 and 3.30 pmol protein- $\mathrm{N}$ cell ${ }^{-1}$ obtained by converting the range of the measured cellular protein (Kamykowski et al. 1998b) to the range of nitrogen-in-measured-protein using the fact that the weight of nitrogen in protein is about $20 \%$ of the weight of the protein. The estimated nitrogen-in-measured-protein is low compared to total cell nitrogen because of a conservative estimate of nitrogen:carbon by weight (DiTullio 1993) and because the measured protein under nutrient replete conditions probably represents only a portion of the total protein (Dortch et al. 1984, DiTullio 1993). Since this component does not critically affect the operation of the model, in the present model, modeled protein is scaled to the measured protein in Kamykowski et al. (1998b) although it is considered a low estimate compared to total protein. Hereinafter, the term protein is used to represent the scaled protein. As more information is gained on protein of Gymnodinium breve, the protein value can be easily adjusted. The sum of these 2 forms of nitrogen counts for all the internal nitrogen in the modeled cell with the range from $6.32\left(N_{\min }\right)$ to $23.30 \mathrm{pmol} \mathrm{N} \mathrm{cell}^{-1}\left(N_{\max }\right)$. This generally agrees with the range of the internal cellular nitrogen measured by Heil (1986), which was approximately from 3.3 to $15.4 \mathrm{pmol} \mathrm{N} \mathrm{cell}{ }^{-1}$. For convenience, the percentage of the nitrogen-in-protein in the total internal cellular nitrogen in our model is considered as a constant, and $13.1 \%$ is used to calculate nitrogen-in-protein from the total internal cellular nitrogen for the purpose of calculating the rate of internal carbon being built into cellular protein, which will be discussed below.

The value of $V_{\max }$ is determined using the following method. Because the range of the internal cellular nitrogen pool is between 6.32 and $23.30 \mathrm{pmol} \mathrm{N} \mathrm{cell}^{-1}$, the poorest possible daughter cell has $6.32 \mathrm{pmol} \mathrm{N} \mathrm{cell}^{-1} \mathrm{ni}-$ trogen in the cell and the richest possible daughter cell has $16.98 \mathrm{pmol} \mathrm{N} \mathrm{cell}^{-1}$. Because the measured division interval $\left(T_{\text {div }}\right)$ is $3 \mathrm{~d}$ for the quantized Gymnodinium breve cells in the experiment under nutrient-replete conditions and there is essentially no division of the $G$. breve cells occurring during the $3 \mathrm{~d}$ experiment period, we assume that the poorest cells and the richest cells are all capable of filling up their internal nitrogen pool to be division-ready in $3 \mathrm{~d}$. Dinoflagellates usually divide during a period of few hours prior to sunrise (D.K. pers. obs.); hence, in our model, a $3 \mathrm{~h}$ period prior to sunrise on each day is set as the reproduction period (see 'Cell reproduction strategy'). The initial time of our model simulation is at 03:00 h, i.e., the starting time of the reproduction period, assuming that all the cells are fresh new daughters at that moment (see 'Initial conditions and forcing of the simulation'). Thus, we assume that poorer cells have higher nitrogen uptake rate and richer cells have lower nitrogen uptake rate and that the poorest cells take $72 \mathrm{~h}$ to fill up their internal nitrogen pool to $23.30 \mathrm{pmol} \mathrm{N} \mathrm{cell}^{-1}$ (at the starting time of the reproduction period $3 \mathrm{~d}$ later) and the richest cells take $52 \mathrm{~h}$ to fill up the pool $(1 \mathrm{~h}$ after the reproduction period $2 \mathrm{~d}$ later to prevent these cells dividing on the third day). Although light/dark modulation of nutrient uptake is likely (Cullen 1985) and nitrogen uptake rate may be higher during the light period and lower during the dark period (Flynn et al. 1996, Flynn \& Flynn 1998), this feature is neglected here until more information on G. breve is available. Under these assumptions, an exponential nitrogen uptake rate as a function of the internal cellular nitrogen is proposed here:

$$
V_{\max }=5.46 \mathrm{e}^{-0.186 N}
$$


Note that the units of $V_{\max }$ given by this expression are pmol $\mathrm{N} \mathrm{cell}^{-1} \mathrm{~h}^{-1}$. The average nitrogen uptake rate for the poorest daughter cells is about $0.236 \mathrm{pmol} \mathrm{N}$ cell $^{-1}$ $\mathrm{h}^{-1}$ (i.e. the average rate for the cells to fill $16.98 \mathrm{pmol}$ $\mathrm{N}$ cell $^{-1}$ deficit in $3 \mathrm{~d}$ ) and the rate for the richest daughter cells is about $0.122 \mathrm{pmol} \mathrm{N} \mathrm{cell}^{-1} \mathrm{~h}^{-1}$ (i.e., the average rate for the cells to fill $6.32 \mathrm{pmol} \mathrm{N} \mathrm{cell}^{-1}$ deficit in $3 \mathrm{~d}$ ). The mean value of these 2 average nitrogen uptake rates is about $0.179 \mathrm{pmol} \mathrm{N}$ cell $^{-1} \mathrm{~h}^{-1}$ and is close to the maximum nitrate uptake rate of $0.14 \mathrm{pmol}$ $\mathrm{N}$ cell ${ }^{-1} \mathrm{~h}^{-1}$ reported by Steidinger et al. (1998) for $G$. breve under nutrient replete conditions.

Finally, the formula used for carbon lost to protein synthesis in Eq. (24) is

$$
\frac{\mathrm{d} C n_{\text {protein }}}{\mathrm{d} t}=0.814 \cdot V_{\max }\left(1-\frac{K_{\mathrm{q}}}{0.869 \cdot N}\right)
$$

Since this protein is a constant percent of total nitrogen, $N$, the latter is used in model output comparisons to the laboratory data. See Liu (2000) for a detailed derivation of this equation.

In the model we use the mid-point value of any interval to represent the values of all the cells in that interval. Thus it is necessary to point out how we determine the minimum and the maximum value of each independent variable in a discrete fashion. For internal cellular carbon and nitrogen, we set the observed minimum and maximum values at the mid-points of the first and last intervals, respectively, on the corresponding variable axes. The minimum and maximum values of these variables in the model are set half a grid interval lower and higher than the observed minimum and maximum values, respectively. For photoinhibition, because the inhibition of the cells in the highest box and the lowest box need to be 1 and 0 , respectively, we set the mid-point values of the first and the last intervals to zero and 1, respectively; thus the modeled minimum and the maximum values are smaller and higher than zero and 1, respectively. For 3 d PAR exposure, the lower boundary of the lowest interval is set to zero and the upper boundary of the highest interval is set to 1. This completes the specification of the internal advective velocities.

\section{Cell swimming behavior}

The migratory behavior consists of 2 separate but interrelated components, swimming speed and swimming orientation. They are summarized in Table 2 with the descriptions and formulae given in Appendix 1. Unlike the advective velocities given previously, which were based on earlier independent experiments, our hypothesized swimming rules, while reasonable, are based to a great extent on the experiment we seek to simulate. Indeed, one objective of this work is to develop swimming rules which replicate the previously described experimental results. Thus we may view this numerical experiment as one in model calibration rather than model verification. The swimming

Table 2. Hypothesized swimming rules. The threshold values of $H_{\mathrm{C}}, C$, and $N$ are fractions of the ranges between the minimum and maximum values of the respective variables. PAR intensity [i.e., $I(z)]$ is expressed in $\mu \mathrm{mol} \mathrm{quanta} \mathrm{m}^{-2} \mathrm{~s}^{-1}$, and $\left[N O_{3}\right]$ and $K_{N}$ are expressed in $\mu \mathrm{M} \mathrm{NO} \mathrm{NO}_{3}-\mathrm{N}$

\begin{tabular}{|c|c|c|}
\hline $\begin{array}{l}\text { Independent variable ranges for swimming } \\
\text { orientation control }\end{array}$ & Swimming direction & $\begin{array}{l}\text { Number of corresponding } \\
\text { equation for swimming speed }\end{array}$ \\
\hline \multicolumn{3}{|c|}{$\begin{array}{l}\text { During the light period (i.e., between } 06: 00 \text { and } 18: 00 \mathrm{~h} \text { ) } \\
\text { If } H<0.8 \text { and }\end{array}$} \\
\hline$C<0.6$ & Up & (A2) \\
\hline $0.6 \leq C<0.95$, and $I(z)<17.5$ & Up & (A2) \\
\hline $0.6 \leq C<0.8$, and $I(z) \geq 17.5, N \geq 0.9$ & Rest & - \\
\hline $0.6 \leq C<0.8$, and $I(z) \geq 17.5, N<0.9$ & Down & (A4) \\
\hline $0.8 \leq C<0.95$, and $I(z) \geq 17.5$ & Down & (A4) \\
\hline$C \geq 0.95$ & Down & (A4) \\
\hline If $H_{\mathrm{c}} \geq 0.8$ & Down & (A3) \\
\hline \multicolumn{3}{|l|}{ During the dark period between $18: 00$ and $00: 00 \mathrm{~h}$} \\
\hline All & Down & (A5) \\
\hline \multicolumn{3}{|c|}{ During the dark period between 00:00 and 04:00 $\mathrm{h}$} \\
\hline$\left[N_{3}\right]<3.0 K_{N}(=1.26)$ & Down & (A5) \\
\hline$\left[N O_{3}\right] \geq 3.0 K_{N}(=1.26)$ & Rest & - \\
\hline \multicolumn{3}{|c|}{ During the dark period between 04:00 and 06:00 $\mathrm{h}$} \\
\hline$C<0.1$ or $N \geq 0.9$ & Up & $(\mathrm{A} 7)$ \\
\hline All others & Rest & - \\
\hline
\end{tabular}


rule parameters were tuned to give reasonable results, but we have not tried to finely tune these parameters. This was done as some of the observed variables, e.g., lipids and protein, are only measures of those predicted, e.g., internal carbon and nitrogen. Lipids are emphasized compared to carbohydrates (Cullen 1985) because they appear to be dominant storage component in Gymnodinium breve (Kamykowski et al. 1998b).

The formulas for determining the swimming speed in our model are developed based on the laboratory observations on Gymnodinium breve (Heil 1986, Kamykowski et al. 1998b,c). The formulations by Kamykowski \& McCollum (1986) and Kamykowski et al. (1988) for several other dinoflagellate species, which are considered comparable to G. breve, are also utilized, as not all corresponding observations have been made on $G$. breve itself. The parameters in the formulations are expected to vary among species. The parameters obtained for Gyrodinium dorsum by Kamykowski \& McCollum (1986) are used for G. breve in our model except that the maximum swimming speed of G. breve is taken as $1 \mathrm{~m} \mathrm{~h}^{-1}$ (Heil 1986). The swimming speed given by Kamykowski et al. (1988) model is temperature, light, and buoyancy acclimated and simplified to be incorporated into our model. Four different time regimes, each with different swimming rules are postulated. Here we give a qualitative description of the rules (more details and formulas are given in Appendix 1 and Table 2): (1) During the light period, cells which are very high in carbon or are highly photoinhibited descend. Cells which are not highly photoinhibited will ascend or descend, primarily based on carbon content. Cells low in carbon ascend, the lower the carbon content the higher the speed, as will cells at moderate content but at low light intensities. Cells at moderate carbon levels and high light intensities will rest if their nitrogen content is high but descend, seeking nutrients, if their nitrogen content is low. (2) During the second period, from 'sunset' (lights-out) to midnight, all cells descend to find nutrients. However, the descent speed decreases for cells at higher internal nitrogen levels or higher external nitrate locations. The descent speed decreases most rapidly for small increases in nitrogen content when the nitrogen content is at 0.9 of the full range. (3) During the period from midnight to 04:00 h, cells at low external nitrate locations continue to descend while others rest. (4) During the final period from 04:00 $\mathrm{h}$ to 'sunrise' (lights-on), cells which are very low in carbon or very high in nitrogen ascend, while all others rest.

The transition points, i.e., the values of the variables at which changes in behavior occur, were chosen to obtain reasonable results; this is consistent with the calibration role of this work.

\section{Cell reproduction strategy}

The final element of our model is reproduction. Kamykowski et al. (1998b) proposed 2 hypotheses (dynamic temporal mechanism and less dynamic multicell mechanism) to explain the possible reasons for the divergence in the internal biochemical composition between the cells at the surface and the cells at midcolumn during the light period in their experiment. In the dynamic temporal mechanism, 2 daughter cells coming from a parent cell are the same biochemically, and all the parent cells are the same as each other. Time lags for different cells to reach the surface may cause the difference in cell behavior and consequently the divergence in the biochemical composition. On the other hand, in the less dynamic multi-cell mechanism, 2 daughter cells coming from a parent cell may be different and parent cells may be different from each other. The behavior difference between cells of different types may be the reason for the measured divergence in the biochemical composition. Kamykowski et al. (1998b) further stated, 'In reality, a continuous spectrum of different types of cells may exist.' Hence, 2 reproduction strategies are chosen for our model run: the least equal-daughter reproduction strategy and the equal-daughter reproduction strategy. By 'the least equal daughter reproduction strategy,' we mean one daughter (the poor daughter) gets the minimum amounts of internal carbon and nitrogen and the other (the rich daughter) gets the remainder of each constituent. By 'the equal daughter reproduction strategy,' we mean both daughters get the same amounts of these internal cellular biochemical constituents. The simulation results of the 2 different reproduction strategies will be compared with the observations.

Dinoflagellates usually divide during a period of few hours around sunrise. In our model, a $3 \mathrm{~h}$ period prior to sunrise is set as the reproduction period. Reproduction is taken to occur when a cell's internal nitrogen is at its maximum, i.e., $23.30 \mathrm{pmol} \mathrm{N} \mathrm{cell}^{-1}\left(N_{\max }\right)$ and its internal cellular carbon pool exceed $90 \%$ of the ranges, i.e., 85 pmol $\mathrm{C} \mathrm{cell}^{-1}\left(\mathrm{Cn}_{\text {div }}\right)$. The division threshold of internal cellular carbon at $90 \%$ of the range is to allow the occurrence of the division of high carbon cells after $9 \mathrm{~h}$ overnight carbon loss due to dark respiration and protein synthesis. The daughter cells are assumed to keep the same values of the cumulative photoinhibition and the $3 \mathrm{~d}$ PAR exposure as their parents.

This completes the model description. Thus, given a concentration of cells at an initial time, Eq. (6) is solved by the algorithm given in Eqs. (9) \& (10). The generalized velocities, which are functions of the external fields and internal independent variables are given in Eqs. (14), (16), (24) \& (25) and in Appendix 1. 
The above model can be used in a Lagrangian manner. Starting at its initial position and internal states, the changes in location and internal states of a single cell can be treated using the equations given above. However, as the experiment encompasses $4.5 \times 10^{9}$ cells, it is not practical to track each cell. A smaller number of cells could be tracked; each cell would represent a specified number of cells with nearly the same initial position and internal states of the tracked cell. Given the specified sensitivity of the swimming speed to internal states, the range of internal states that a single cell could represent would be quite small. Two cells starting at the same location and differing by only 1 pmol internal carbon might find themselves vertically $1 \mathrm{~m}$ apart at the end of $3 \mathrm{~d}$. As this is on the order of the vertical extent of the mesocosm, the range in carbon represented by a tracked cell would have to be less than 1 pmol internal carbon. A series of numerical experiments would be necessary to find the appropriate number of cells to be tracked. The Eulerian approach utilized here is relatively easy to implement.

\section{INITIAL CONDITIONS AND FORCING OF THE SIMULATION}

The model configuration for simulating the $3 \mathrm{~d}$ experimental observations by Kamykowski et al. (1998b,c), which was briefly described earlier, is given in this section, and the model results and the comparison with the observations are presented in the next section. The model results presented here are for 3 different cases. In the first 2 cases, the model is run for $3 \mathrm{~d}$ using the 2 different reproduction strategies, first the least equal daughter reproduction strategy and second the equal daughter reproduction strategy, introduced in the last section. Because the laboratory observations by Kamykowski et al. $(1998 b, c)$ were over a 3 d period, our simulations also focus on a $3 \mathrm{~d}$ period. A comparison with the published data of Kamykowski et al. (1998b,c) will be undertaken. In the third case, a $10 \mathrm{~d}$ run using the least equal daughter reproduction strategy with the same initial conditions is conducted to investigate how the population and the average vertical distribution of its internal cellular biochemical composition may evolve over a longer period under the hypotheses developed in our model.

For the $3 \mathrm{~d}$ cases, the model run starts from 03:00 $\mathrm{h}$ on the first day and ends at 06:00 h on the fourth day. For the $10 \mathrm{~d}$ case, the model run starts from 03:00 $\mathrm{h}$ on the first day and ends at 06:00 $\mathrm{h}$ on the eleventh day. The initial time is set at 03:00 $\mathrm{h}$ instead of 06:00 $\mathrm{h}$ as in the experiment because our initial cells are assumed to all be fresh new daughter cells and the simulations (shown in the next section) show that the overwhelm- ing majority of the reproducing cells divide at the beginning time of the $3 \mathrm{~h}$ reproduction period, i.e., at 03:00 h.

The external environmental conditions and initial conditions are set as closely as possible to the corresponding conditions in the experiment. The depth of the model domain is $1.60 \mathrm{~m}$. The external nitrogen concentration is set to a constant $150 \mu \mathrm{M} \mathrm{NO}_{3}-\mathrm{N}$ independent of depth and time. Under this external nitrate concentration, the calculated nutrient uptake rate is about $99.72 \%$ of the potential internal cellular nitrogen determined maximum uptake rate (from Eq. 25). A constant $350 \mu \mathrm{mol}$ quanta $\mathrm{m}^{-2} \mathrm{~s}^{-1}$ PAR is on a $12 \mathrm{~h}$ light:12 h dark cycle, with light hours from 06:00 to 18:00 $\mathrm{h}$ on each day. Under $350 \mu \mathrm{mol}$ quanta $\mathrm{m}^{-2} \mathrm{~s}^{-1}$ PAR, the light acclimated swimming speed, $S_{\text {accli, }}$ is $1.009 \mathrm{~m} \mathrm{~h}^{-1}$ and during the dark period it is $0.75 \mathrm{~m} \mathrm{~h}^{-1}$. The initial cell concentration at $03: 00 \mathrm{~h}$ on the first day is 2800 cells $\mathrm{ml}^{-1}$ uniformly distributed through the water column. All these cells are the fresh daughter cells newly derived from the parent cells at a density of 1400 cells $\mathrm{ml}^{-1}$. The parent cells' internal nitrogen amounts are all at the maximum, and these parent cells are uniformly distributed over 90 through $100 \%$ of the internal carbon range. The initial biochemical compositions of these daughter cells are distributed from their parents according to the corresponding reproduction strategies considered in the simulations. The initial photoinhibition is set to zero for all the cells because the simulation starts at 03:00 $\mathrm{h}$, when the PAR has been zero for $9 \mathrm{~h}$.

In the model, equal grid spacing is used for all the axes except the $3 \mathrm{~d}$ PAR exposure. The numbers of grid points for the different axes are different: 8 grid points for depth, 40 for carbon, 40 for nitrogen, 5 for photoinhibition, and 5 for $3 \mathrm{~d}$ PAR exposure. All the grid points are set at the centers of the corresponding discrete intervals, and any cell in any interval is considered to have the state at its mid-point (the grid point). All the cells in any interval are uniformly distributed through the interval. The $3 \mathrm{~d}$ PAR exposure variable axis is discretized into 5 non-uniform intervals by setting the upper boundaries of the five $3 \mathrm{~d}$ PAR exposure reference layers at 5 evenly spaced depths, $Z T=0,0.32$, $0.64,0.96$, and $1.28 \mathrm{~m}$, with an additional end point set at infinity below the surface. Then the mid-point values of these intervals are determined by the approach discussed in the section of model description earlier. The scale factor $(S C)$ of the $3 \mathrm{~d}$ PAR exposure calculated by the method mentioned earlier is approximately 1.85 for the constant illumination of $350 \mu \mathrm{mol}$ quanta $\mathrm{m}^{-2} \mathrm{~s}^{-1}$. The $3 \mathrm{~d}$ PAR exposure determined by this method is from zero though about $190 \mu$ mol quanta $\mathrm{m}^{-2} \mathrm{~s}^{-1}$ in our model configuration. The $3 \mathrm{~d}$ PAR exposure values at the 5 grid points and the related sun- 
Table 3. Grid points of sun-shade acclimation (i.e., $3 \mathrm{~d}$ PAR exposure) variables and values of sun-shade acclimated parameters at the corresponding grid points

\begin{tabular}{|c|c|c|c|}
\hline $\begin{array}{l}3 \mathrm{~d} \text { PAR exposure } \\
\text { at the grid points, } \\
E_{3} \\
\left(\mu \mathrm{mol} \text { quanta } \mathrm{m}^{-2} \mathrm{~s}^{-1}\right)\end{array}$ & $\begin{array}{c}\text { Sun-shade acclimated } \\
\text { saturation light intensity, } \\
I_{k} \\
\left(\mu \mathrm{mol} \text { quanta } \mathrm{m}^{-2} \mathrm{~s}^{-1}\right)\end{array}$ & $\begin{array}{l}\text { Sun-shade acclimated PAR threshold for } \\
\text { inducing instantaneous photoinhibition, } \\
\qquad I_{\mathrm{h}} \\
\qquad\left(\mu \mathrm{mol} \text { quanta } \mathrm{m}^{-2} \mathrm{~s}^{-1}\right)\end{array}$ & $\begin{array}{c}\text { Sun-shade acclimated } \\
\text { maximum photosynthetic rate, } \\
P_{\mathrm{m}} \\
\left(\mathrm{pmol} \mathrm{C} \mathrm{cell}^{-1} \mathrm{~h}^{-1}\right)\end{array}$ \\
\hline 4.10 & 4.10 & 13.20 & 0.420 \\
\hline 13.09 & 13.09 & 31.18 & 0.427 \\
\hline 28.70 & 28.70 & 62.40 & 0.474 \\
\hline 62.93 & 62.93 & 130.86 & 0.857 \\
\hline 138.00 & 138.00 & 280.99 & 0.917 \\
\hline
\end{tabular}

shade acclimated parameters are given in Table 3 . The initial $3 \mathrm{~d}$ exposure values of all the cells in the population are set arbitrarily to the value of $28.70 \mu \mathrm{mol}$ quanta $\mathrm{m}^{-2} \mathrm{~s}^{-1}$, which is the intermediate (i.e., the third interval) in the five $3 \mathrm{~d}$ PAR exposure intervals ranging from $4.10 \mu \mathrm{mol}$ quanta $\mathrm{m}^{-2} \mathrm{~s}^{-1}$ to $138.0 \mu \mathrm{mol}$ quanta $\mathrm{m}^{-2} \mathrm{~s}^{-1}$ (Table 3).

With these settings of the grid spacings and the corresponding advection speeds, to meet the CFL numerical stability criterion and to reduce the computing time, 2 time steps are used in our model. First a $5 \mathrm{~min}$ time step is used to update the population due to advective processes in nitrogen, photoinhibition, and swimming. Using this updated population, the advective change in population due to carbon and sun-shade acclimation is updated using a $10 \mathrm{~min}$ time step and the advective changes due to nitrogen, photoinhibition, and swimming are computed using another $5 \mathrm{~min}$ time step. The total advective changes due to all variables then define a new population at the end of the $10 \mathrm{~min}$ interval. Since there are 40000 distinct internal states (or types of cells) in each of 8 layers, far too much data is accumulated to be retained. Therefore, each hour (every 6 full time steps) only the number of cells in each layer and for the cells in each layer, the population mean values and standard deviations of each internal state are retained in a computer file.

\section{SIMULATION RESULTS AND DISCUSSION}

In this section we shall compare model predictions with the observations given in Kamykowski et al. (1998b,c). For a more complete discussion and more details see Liu (2000). We first briefly discuss the experimental data to which our simulated results will be compared. Fig. 1, redrawn from Kamykowski et al. (1998c), gives the relative fluorescence (proportional to cell density) as a function of depth and time. These data are based on fluorescence profiles performed every 2 h. Fig. 2, redrawn from Kamykowski et al. (1998b), gives cell density, lipid/cell, and protein/cell information based on 6-hourly samples at the surface and at $0.75 \mathrm{~m}$ depth. The lipid (measured protein) will be compared to simulated carbon (nitrogen) content. Observations will now be compared with the $3 \mathrm{~d}$ runs of Cases 1 and 2.

\section{Case 1: A three-day simulation using the least equal daughter reproduction strategy}

Initially, $5.6 \times 10^{8}$ cells are assigned to each of the 8 layers. The initial box numbers for the $3 \mathrm{~d}$ PAR exposure and cumulative photoinhibition, as discussed above, are $j_{E_{3}}=3$ and $j_{H_{c}}=1$ for all cells. One half the cells have $j_{N}=1$ and $j_{C n}=1$, the poor daughters. One

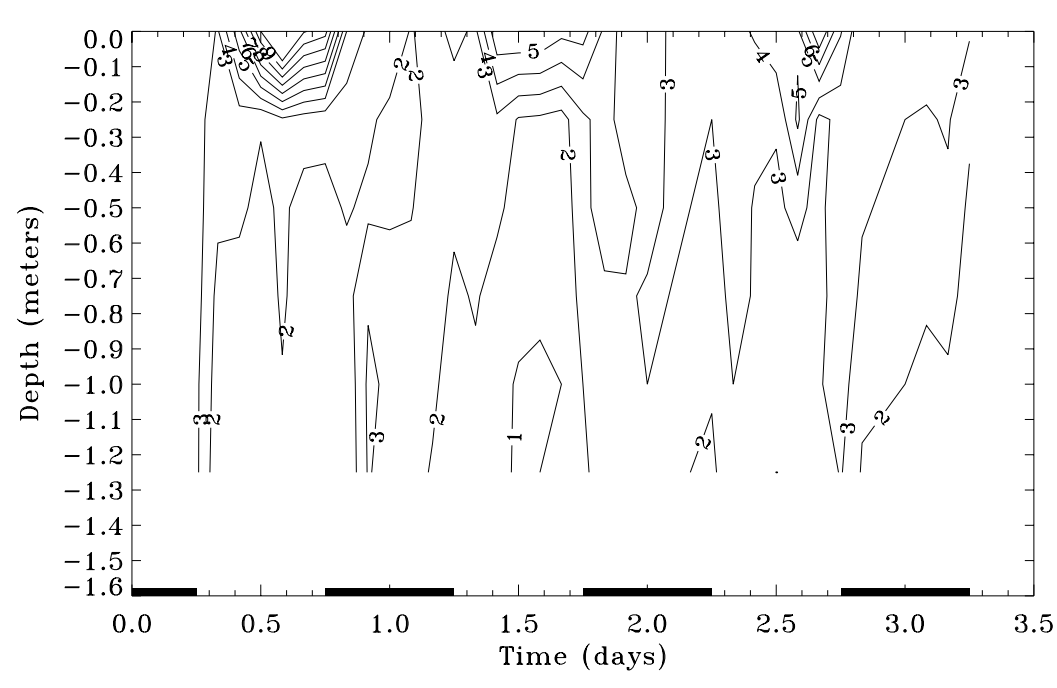

Fig. 1. Gymnodinium breve diel vertical migration displayed as contours of in vivo fluorescence profiles obtained from the mesocosm at $2 \mathrm{~h}$ intervals over a $72 \mathrm{~h}$ period (redrawn from Kamykowski et al. 1998c). The closed bars along the $x$-axis mark the dark period 

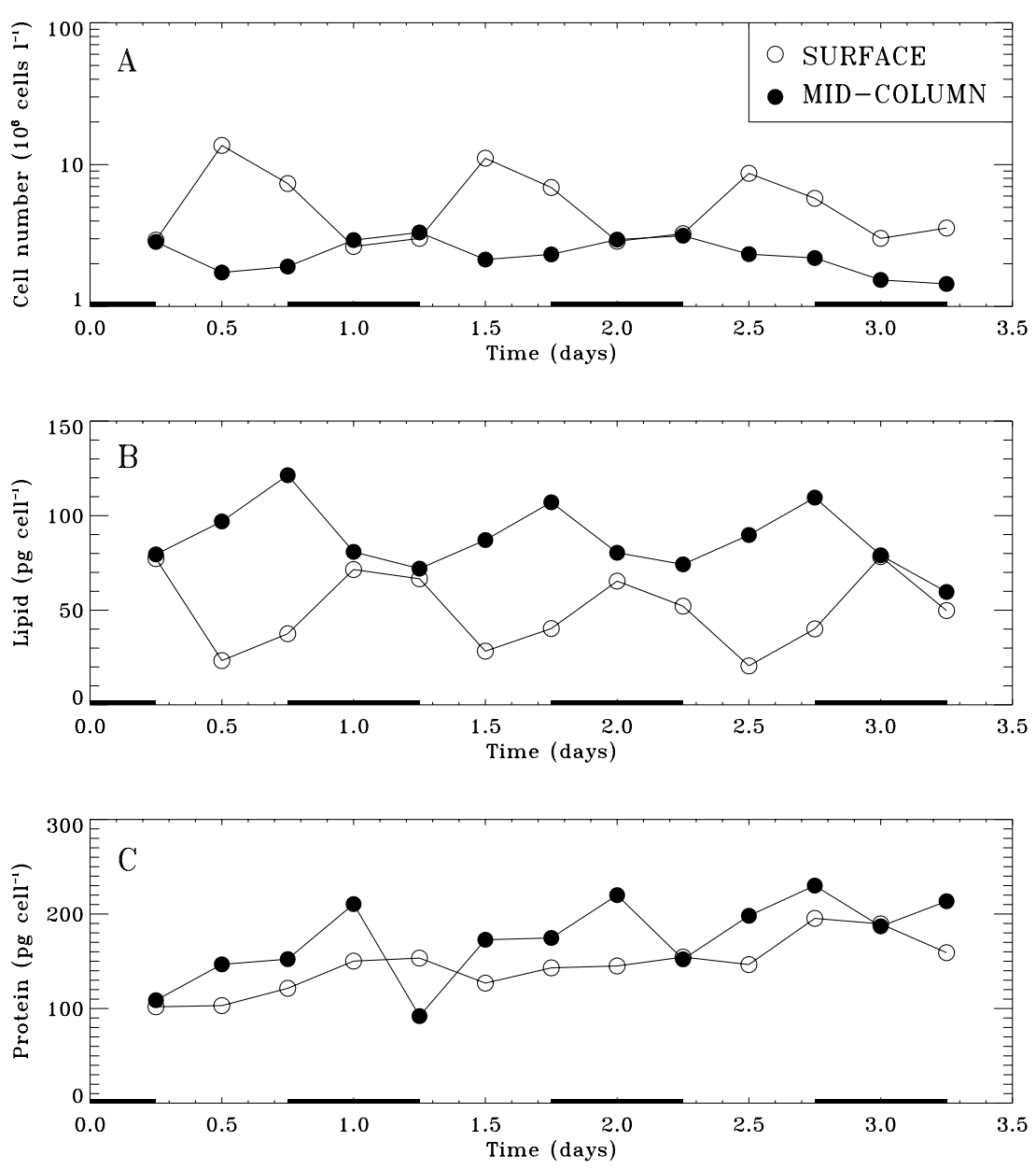

Fig. 2. Time course of (A) cell concentration, (B) lipid, and (C) protein for surface and mid-column mesocosm Gymnodinium breve samples at $6 \mathrm{~h}$ sampling intervals over a $72 \mathrm{~h}$ period (redrawn from Kamykowski et al. 1998b). The closed bars along the $x$-axis mark the dark period concentrations in both from the first to the second to the third day. This pattern is easy to understand from the perspective of our model. Ascent speeds are taken to decrease as the carbon content of the cell increases. Initially all cells are low in carbon, which produces relatively high ascent speeds in Day 1. Due to photosynthesis during Day 1, the carbon content of cells increases by the start of Day 2 and ascent speeds diminish; this process continues as we move to the light period of Day 3. Photoinhibition induced descent also plays a role in this day-to-day decrease of surface maximum concentrations. A model run (not shown) with photoinhibition induced descent turned off shows increased surface aggregation of 2, 18 and $48 \%$ over the Case 1 results at noon on Days 1, 2, and 3 , respectively. Thus photoinhibition plays an increasingly important role as time goes by. This can be explained as follows: in Day 1, strong carbon deficit induced surface concentrations increase the near-surface values of the decay constant for PAR, ek $(z, t)$, and while ascending cells experience higher PAR values and get slightly photoinhibited. Their photoinhibition is less than it would be without self-shading. In subsequent light periods, the carbon- eighth of the initial population in each layer is assigned to each of 4 boxes with $j_{N}=26$ and $j_{C n}=15,16,17,18$, the rich daughters. The range in carbon in the daughters corresponds to the range in carbon of the mothers, from 90 to $100 \%$ full. We now turn to the results.

Fig. 3 shows the simulated cell concentrations as a function of time and depth. The pattern in this figure may be compared with the fluorescence pattern in Fig. 1. Cell concentration values will be discussed below. Strong surface aggregations during the light period with the maximum surface cell concentration occurring around noon are present in the data and the model results, with diminishing maximum

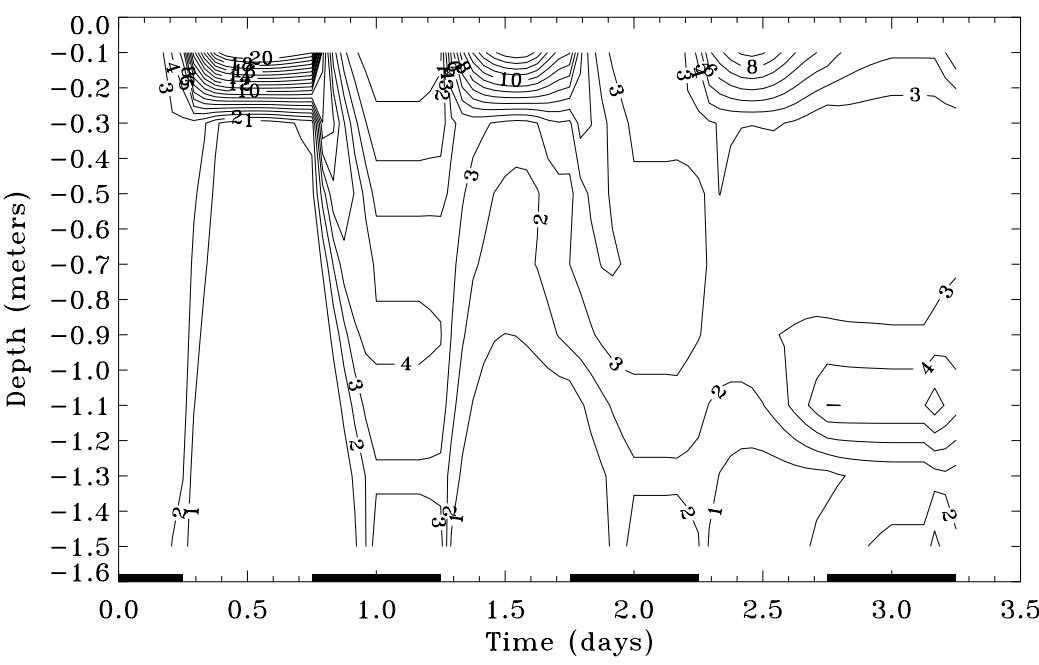

Fig. 3. Least equal daughter reproduction strategy. Simulated vertical cell distribution over a $3 \mathrm{~d}$ period. Units are $10^{6}$ cells $\mathrm{l}^{-1}$ 
induced surface aggregation diminishes as does the effect of surface aggregation on ek $(z, t)$ and cells can become more photoinhibited, leading to increased descent and reduced surface aggregation as time progresses. As in the observations, during the dark period the cell concentration (Figs. 3 \& 4A) is fairly uniform through the water column from the surface through to the bottom; however, the number of cells remaining at the surface during the dark period increases over the $3 \mathrm{~d}$. The simulated daily surface aggregation starts before the light period, as in the experiment, by ascent of very low carbon or very high nitrogen cells (see Appendix 1 for the thresholds). We turn next to a comparison of biochemical components at 2 depths.

Fig. 4 shows the simulated cell concentration, carbon content, and nitrogen content at 4 depths as a function of time. We shall focus on only 2 of these depths, the solid line $(0.1 \mathrm{~m})$, which we will compare to the open circles (surface) in Fig. 2, and the dashed line $(0.7 \mathrm{~m})$, which we shall compare to the filled circles (mid-column) in Fig. 2. First we consider cell concentration, the top panels in Figs. 2 \& 4A. During the final $2.5 \mathrm{~d}$ both surface and depth data and calculations are in excellent agreement. During the first full day the predicted surface concentrations in the light period are too high (about $50 \%$ ) and during the dark period are too low. The predicted concentrations at depth are too low compared with the data during the first light period but are in good agreement in the subsequent dark period and thereafter. These discrepancies may be associated with the uncertainties associated with prescribing the initial concentration and states of the cells. We have prescribed that there are no mother cells present initially and the 2 types of daughter cells are uniformly distributed with depth. Mother cells actually present and near reproduction would move more sluggishly and thus lower surface concentrations in Day 1 during the light period and raise concentrations at depth. Reproduction of these

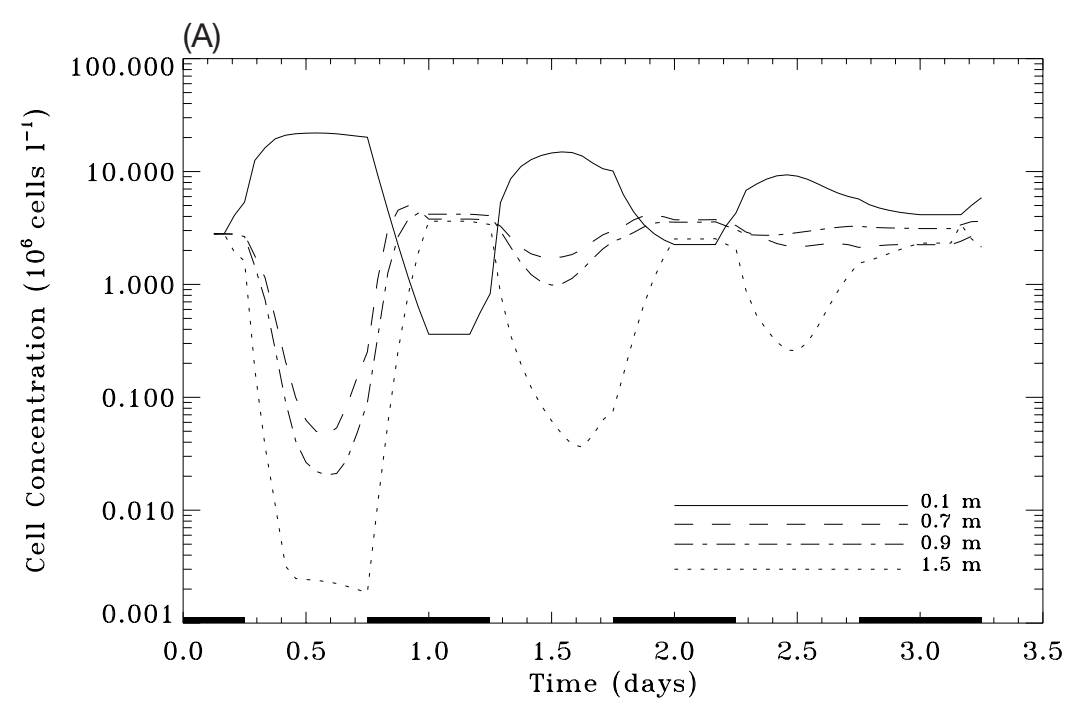

(B)
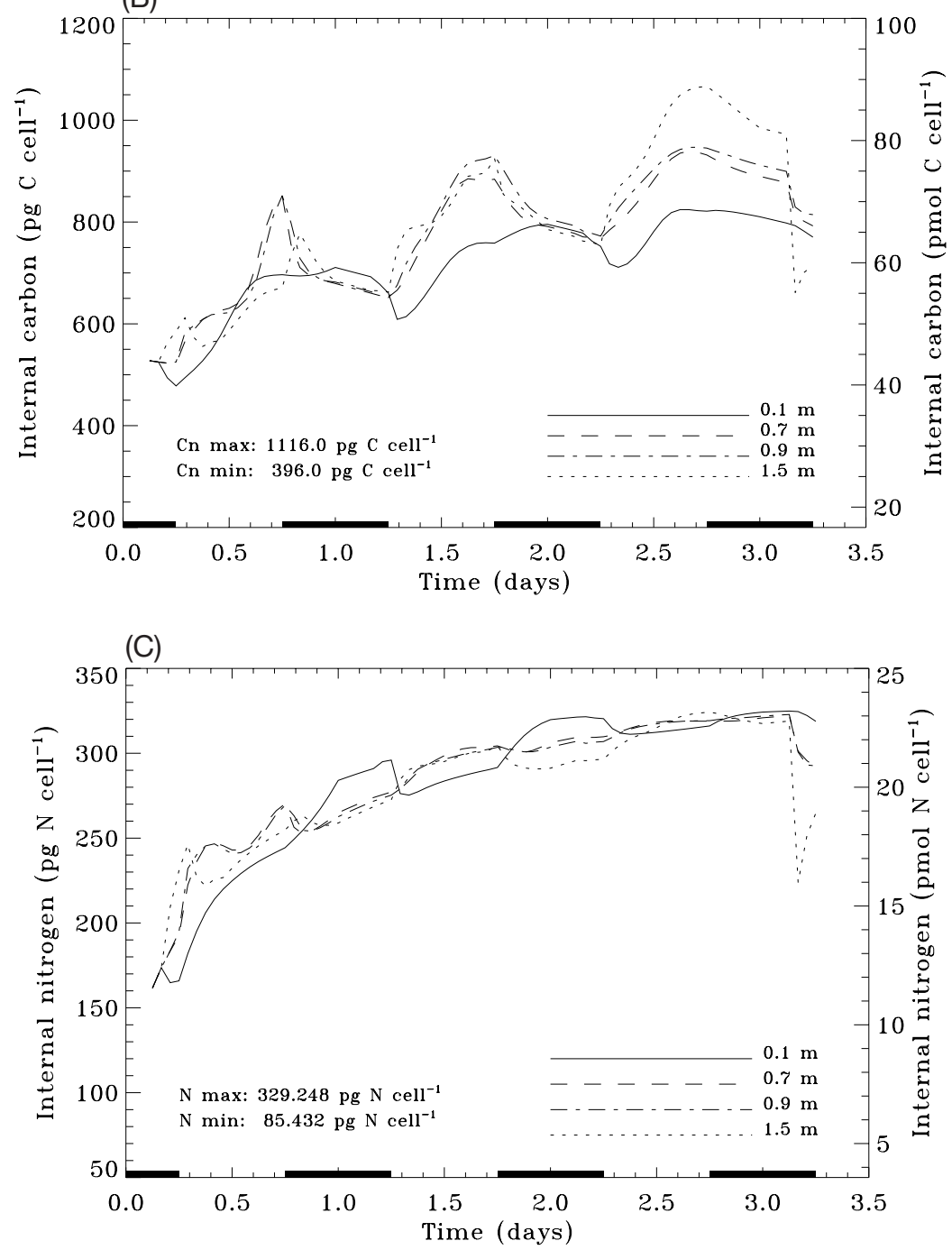

Fig. 4. Least equal daughter reproduction strategy. Simulated (A) cell concentration, (B) average internal carbon, and (C) average internal nitrogen at $0.1,0.7,0.9$, and $1.5 \mathrm{~m}$ depth levels over a $3 \mathrm{~d}$ period 
cells during the first full dark period would bring their daughters' behavior in line with the remainder of the population. Further, the initial values of $E_{3}$ were taken to be uniform at the mid-range value, in the absence of any data; lower values would have increased photoinhibition and decreased surface concentrations. Aspects of the experimental procedures may also contribute to the discrepancies. In the experiment 21 of fluid is withdrawn near the surface every $6 \mathrm{~h}$ and fluorescence profiles are obtained throughout the water column every $2 \mathrm{~h}$. The sampling will differentially decrease the number of poor daughters in the column during the light period, and both processes may induce some mixing which might lower high concentrations, especially when concentration gradients are large, as in the first light period. The temporal decrease in the intensity of surface aggregation was also observed in laboratory monitoring of Gymnodinium breve in the water column, where only fluorescence profiling occurred. We next consider a comparison of the internal biochemical constituents.

We have no direct data on internal carbon and nitrogen from Kamykowski et al. (1998b) and use the measured cellular lipid and protein contents (the bottom 2 panels of Fig. 2) as proxies for these variables respectively. Note that quantitative comparison of the $\mathrm{C}$ and $\mathrm{N}$ budgets with the measured lipid and protein contents is not possible because the model quotas for $\mathrm{C}$ and $\mathrm{N}$ are based on Heil (1986) and the measured lipid and protein are based on Kamykowski et al. (1998b). The quantitative discrepancies may be due to different experimental conditions or to systematic losses in the protein determinations. Thus we can only compare patterns of fluctuation. Lipids at depth are consistently higher than surface values. The basic observed pattern is that divergence in properties between the surface cells and the mid-column cells occurs during the light period and that convergence occurs during the dark period, when the cells disperse approximately uniformly through the water column. Values of lipid at depth increase during the day then drop during the night. Surface lipids drop early in the light periods then rise through midnight and drop slightly until the onset of light. The same patterns of variation are seen in the simulated carbon content (Fig. 4B). Measured protein/cell is our only available proxy for total nitrogen/cell. As measured protein/cell is only one component for cellular nitrogen under nutrient replete conditions (Dortch et al. 1984) and may only account for 10 to $15 \%$ of the total nitrogen content of the cell as presently derived, the variations of measured protein may only partially represent the variations of total nitrogen content. Measured protein at depth is greater than measured protein at the surface in all but 3 of 13 observations (lower panel of Fig. 2). The predicted nitrogen (Fig. 4C) at depth is greater than nitrogen at the surface about two-thirds of the run but primarily during the light periods. Unlike measured protein, nitrogen at the surface is greater than nitrogen at depth during the dark periods. This occurs in our model as cells high in nitrogen are prescribed to descend more slowly than nitrogen poor cells in the period between 18:00 $\mathrm{h}$ and midnight. This results in an increase of nitrogen/cell in this period as the low nitrogen cells leave the surface more rapidly. Thus the correspondence between nitrogen and measured protein is not as strong as we might like. The variation in the biochemical composition of Gymnodinium breve cells over depth during the light period were also observed in the laboratory experiment by Heil (1986): cells at depth have higher carbon and nitrogen than the surface cells, consistent with the present simulation. There was no observation available from Heil (1986) for the dark period.

While our model predicts no reproduction for most of the simulated period, some population increase is observed in the simulation at the end of the third full dark period, though less than might be expected. From a simple calculation, we can determine that the rich daughter cells, $50 \%$ of the initial population, should have been able to absorb sufficient nitrate and, in the presence of high PAR values and no photoinhibition, create enough carbon to reproduce at the end of the third full dark period; however, our simulation indicates that only $12 \%$ do reproduce then. Even this diminished reproduction is sufficient to account for the sudden drop in properties/cell; the number of cells increases by $12 \%$ in a short time but the total amount of carbon and nitrogen does not. This small population increase results in a $11 \%$ decrease in properties/cell averaged over the entire mesocosm near the end of the simulation. The causes for a diminished reproductive population are 2-fold. First, surface aggregation, which results in large increases of ek near the surface, results in diminished PAR intensities from the surface to mid-depth compared with intensities which would prevail if the cells were dispersed. This directly diminishes carbon production as specified in Eq. (20). Further, cumulative photoinhibition values greater than 0.48 in Days 2 and 3 would reduce total carbon (relative to zero photoinhibition) to below the reproductive level. As discussed earlier, a significant fraction of the population reaches values of photoinhibition exceeding 0.8 on Days 2 and 3 as surface population are diminished by this effect. Thus a combination of photoinhibition and surface aggregation can diminish carbon production and hence the reproductive population at the end of the third full dark period. These model formulations require closer inspection in future experiments. For the comparison with the $10 \mathrm{~d}$ 
simulation (shown below), we note that during the $3 \mathrm{~d}$ simulation the minimum PAR at the $1.5 \mathrm{~m}$ (the deepest grid point of the water column) is about $8.0 \mu \mathrm{mol}$ quanta $\mathrm{m}^{-2} \mathrm{~s}^{-1}$ during the light period.

\section{Case 2: A three-day simulation using the equal daughter reproduction strategy}

This case differs from the preceding one because each of the 2 daughter cells is allocated half the carbon and nitrogen content of their mother cell. In this simulation, as before, $5.6 \times 10^{8}$ cells are assigned to each layer in the vertical. One quarter of these cells were each assigned initially to boxes $j_{E_{3}}=3$, $j_{H_{\mathrm{c}}}=1, j_{N}=28$, and $j_{C n}=6,7,8,9$. The results of this simulation are shown in Fig. 5, which shows cell concentration as a function of depth and time, and Fig. 6, which gives cell concentration, mean carbon content, and mean nitrogen content for 4 layers as a function of time.

The vertical population distribution pattern (Figs. 5 \& $6 \mathrm{~A}$ ) is quite similar to the preceding case (Figs. 3 \& $4 \mathrm{~A})$. However, the simulated divergence pattern in carbon (Fig. 6B) is much less significant for the $3 \mathrm{~d}$ period and even in the opposite divergent direction compared to the observations (Fig. 2) on the first day. The equal daughter reproduction strategy has lower initial maximum carbon values than the rich daughter cells of Case 1. The absence of the mid-column peak in carbon and the higher internal carbon at the surface than at mid-column on the first day (Fig. 6B) occur because no cells have enough carbon to descend during the first light period. In Case 1 the rich daughter cells do descend on Day 1, causing the carbon peak at mid-column. The smaller initial carbon difference between cells, which arises from the small difference between parent cells, may account for a pattern in carbon between the surface cells and the mid-column cells less divergent than in Case 1 over the whole simulation period.

The observed significant divergence pattern in nitrogen (Fig. 2) between the surface and mid-column cells during the light period is not reproduced for the first $2 \mathrm{~d}$ by the model with the equal daughter reproduction strategy (Fig. 6C). In the absence of numerical diffusion the cell population can be spread over 2 intervals along the nitrogen axis. For most of the $3 \mathrm{~d}$ simulation, all layers have nearly the same mean nitrogen/cell content. For the second full dark period, surface values of nitrogen/cell exceed these values at depth. At the start of this dark period, the nitrogen level is at $90 \%$ of the full range. At this value of internal nitrogen, the specified descent velocity is fortuitously most sensitive to small changes in nitrogen level. A $2.5 \%$ increase in nitrogen (1 interval) decreases the descent speed by $30 \%$. This leads to cells low in nitrogen leaving the upper layer more rapidly than those higher in nitrogen, thus increasing the nitrogen/cell for those left in the surface layer. Numerical diffusion along the nitrogen axis also enhances this effect somewhat by extending the range of nitrogen by about 1 or 2 intervals in 40 . In the equal daughter case, had the nitrogen level at the start of the dark period been $5 \%$ higher or lower than it actually was, differences in descent velocities would have been diminished, as would the differences in nitrogen/cell between layers. Thus, the predicted nitrogen/cell for this case is generally far more vertically uniform than for Case 1. As measured protein shows definite difference between the surface and mid-column, we might tentatively state the least equal daughter strategy is the one preferred by the cells; a mix between these 2 extreme reproduction strategies is also a possibility.

In this $3 \mathrm{~d}$ simulation, the effects of cell division on cell concentration and property/cell distribution have not been manifested, as only a small fraction of the cells divide at the end of the simulation. Further the effects of self-shading associated with surface aggregation, which diminishes the PAR values experienced by cells and hence carbon creation, and the impacts of reduced carbon production on reproduction cannot be ascertained in the $3 \mathrm{~d}$ simulation. We now turn to a $10 \mathrm{~d}$ simulation, which may give some insight into this process. 


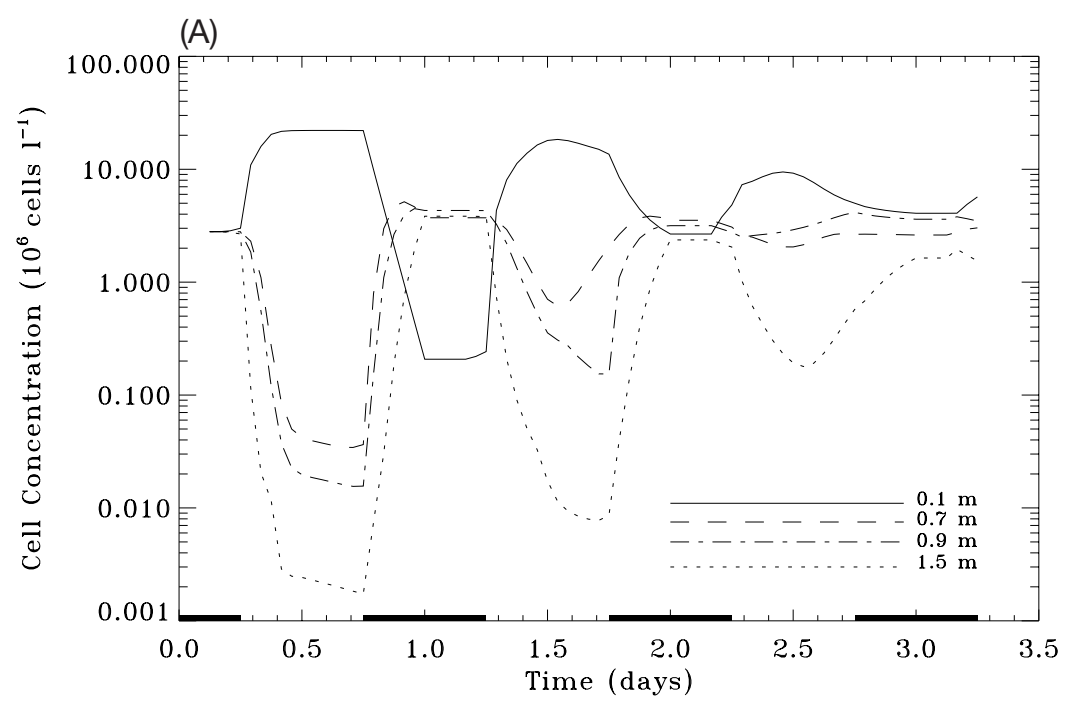

(B)
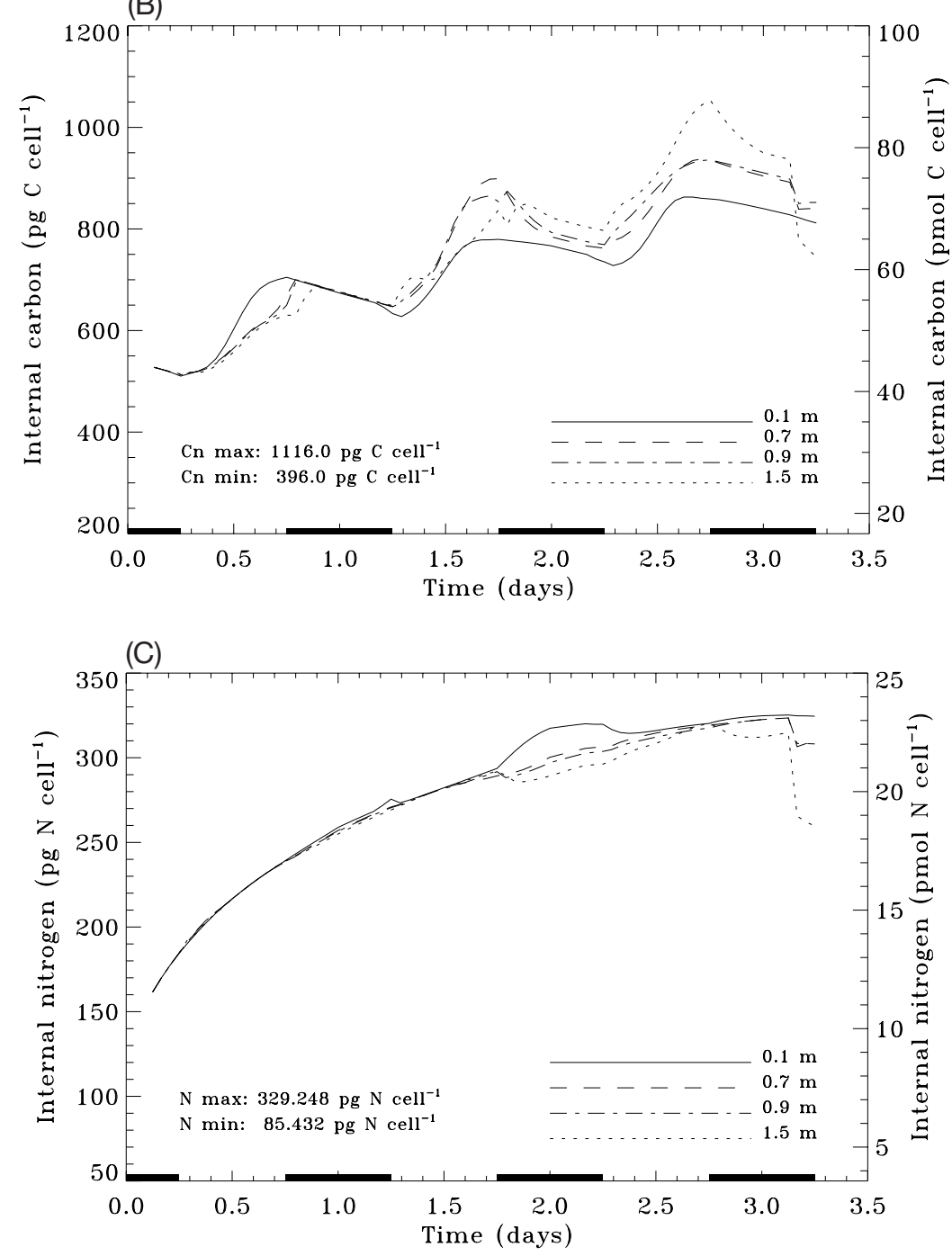

Fig. 6. Equal daughter reproduction strategy. Simulated (A) cell concentration, (B) average internal carbon, and (C) average internal nitrogen at $0.1,0.7$, 0.9 , and $1.5 \mathrm{~m}$ depth levels over a $3 \mathrm{~d}$ period

\section{Case 3: A ten-day simulation using the least equal daughter reproduction strategy}

To further investigate the effect of the self-shading, a $10 \mathrm{~d}$ run is conducted for the least equal daughter scheme; the simulations are shown in the Figs. 7, 8 $\& 9$. The $10 \mathrm{~d}$ simulation shows that the population finally doubles in size on the tenth day (Fig. 8). The simulated final cell number reaches $1.01 \times 10^{10}$ cells in the water column. The self-shading effect becomes more important day by day as more and more cells aggregate at the surface during the $10 \mathrm{~d}$ simulation (Figs. 7A \& 9). That more and more cells are retained in the upper reaches of the column where carbon/cell is lowest indicates that self-shading is having an important effect by decreasing carbon that is photosynthesized and hence slowing the reproductive rate. On the tenth day the highest surface cell concentration reaches $2.64 \times 10^{7}$ cells $^{-1}$ at $11: 00 \mathrm{~h}$ with a PAR attenuation coefficient of $15.81 \mathrm{~m}^{-1}$ and a PAR intensity of only $72.00 \mu \mathrm{mol}$ quanta $\mathrm{m}^{-2} \mathrm{~s}^{-1}$ at $0.1 \mathrm{~m}$. The minimum bottom cell concentration drops to $1.92 \times$

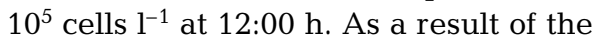
increase in the PAR attenuation coefficient, the depth of the PAR threshold for swimming orientation control for ascent moves upwards in the water column to between 0.1 and $0.3 \mathrm{~m}$ on the tenth day. Thus more cells below this depth tend to move upwards from mid-depths. Consequently, even the lowest surface cell concentration is as high as $7.80 \times 10^{6}$ cells $\mathrm{l}^{-1}$, about $29.60 \%$ of the previous day's highest concentration, during the dark period. The highest bottom cell concentration only rises to $3.04 \times 10^{6}$ cells $\mathrm{l}^{-1}$ at midnight between the tenth and eleventh days. The lowest PAR intensity at $1.5 \mathrm{~m}$ drops below $1.0 \mu \mathrm{mol}$ quanta $\mathrm{m}^{-2} \mathrm{~s}^{-1}$ on the ninth day and further drops to $0.67 \mu \mathrm{mol}$ quanta $\mathrm{m}^{-2} \mathrm{~s}^{-1}$ on the tenth day; this is well below the $3 \mathrm{~d}$ PAR exposure at the mid-point of the lowest interval of the five $3 \mathrm{~d}$ PAR exposure intervals, i.e., $4.10 \mu \mathrm{mol}$ quanta $\mathrm{m}^{-2} \mathrm{~s}^{-1}$. Hence, a higher resolution for $3 \mathrm{~d}$ PAR exposure may be needed for the simulation though few cells are at these depths. The diel oscil- 

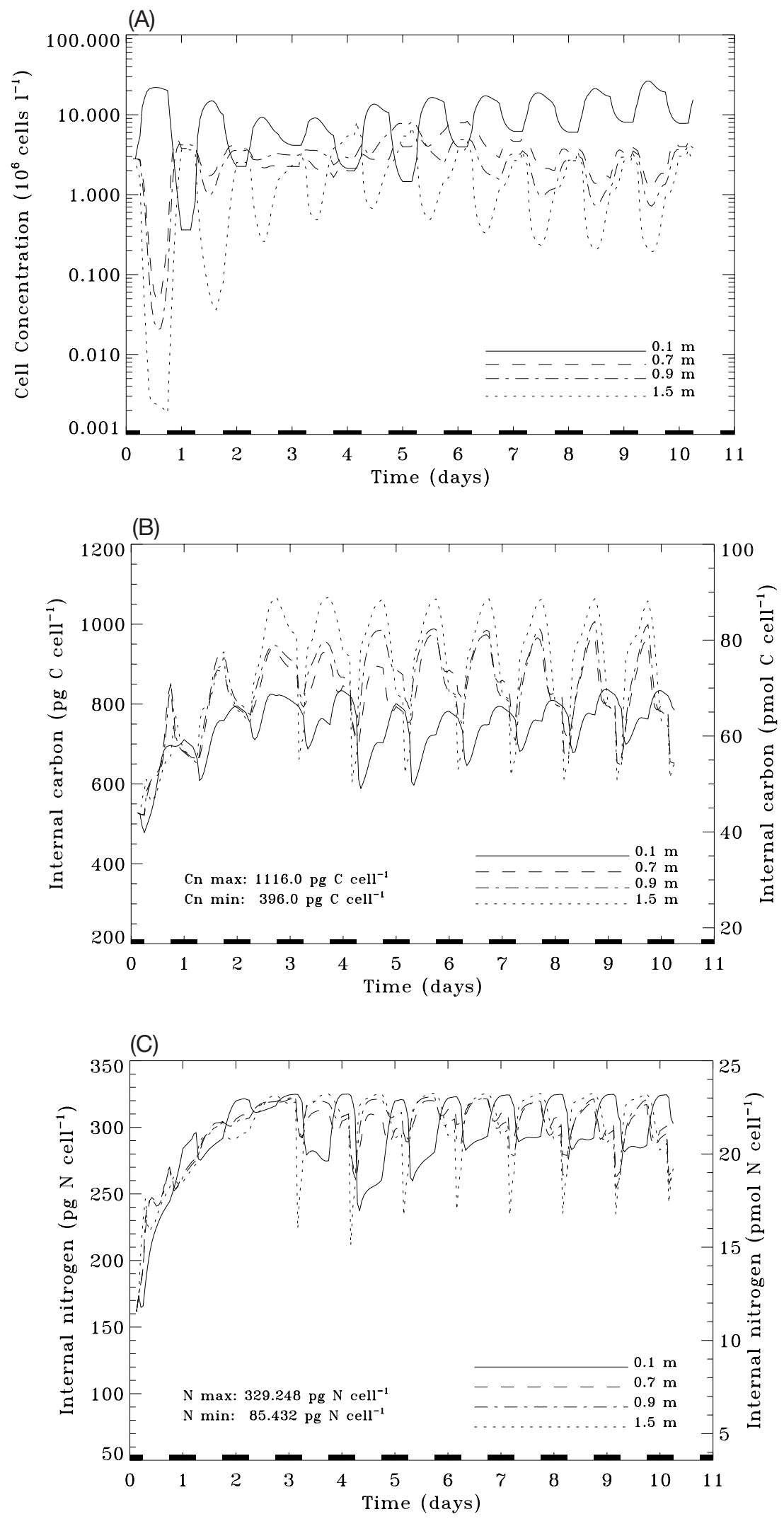

Fig. 7. Least equal daughter reproduction strategy. Simulated (A) cell concentration, (B) average internal carbon, and (C) average internal nitrogen at 0.1 , $0.7,0.9$, and $1.5 \mathrm{~m}$ depth levels over a $10 \mathrm{~d}$ period lation patterns of the internal cellular carbon and nitrogen keep the same convergence and divergence patterns as exhibited in the $3 \mathrm{~d}$ simulation, only to a greater extent in the divergence.

From the $10 \mathrm{~d}$ simulation, we see that the quantization of the Gymnodinium breve cells obtained in Kamykowski et al. (1998b) experiment is generally explained by our simulation. The quantized cell population was obtained by the renewal of the water column from the bottom during the light period, when cells most intensively aggregated at and near the surface. According to the simulation result from our model, this kind of renewal will leave cells with the lowest internal cellular carbon and nitrogen contents in the mesocosm. Under optimal conditions with a much lower cell concentration, these quantized cells may be expected to divide after $3 \mathrm{~d}$.

\section{CONCLUSION}

As was our goal in this work, the model simulations reproduce the basic evolving patterns of population distribution and internal cellular carbon and (possibly) nitrogen distribution patterns observed in the Kamykowski et al. (1998b) experiment and also in the Heil (1986) experiment. Our model may capture the most important mechanisms which control Gymnodinium breve swimming behavior and population dynamics under nutrient replete conditions. Our simulation further demonstrates that internal biochemical and physiological states can play significant and determinative roles in G. breve swimming behavior and consequently in the population dynamics and that the least equal daughter reproduction strategy is likely a component of the reproduction strategy which $G$. breve adopts under nutrient replete conditions.

Ours is the first model to use the Expanded Eulerian Method (EEM) developed by Janowitz \& Kamykowski (1999) to simulate observations; the simulation results demonstrate that the EEM approach is a very robust method for simulating phytoplankton population 


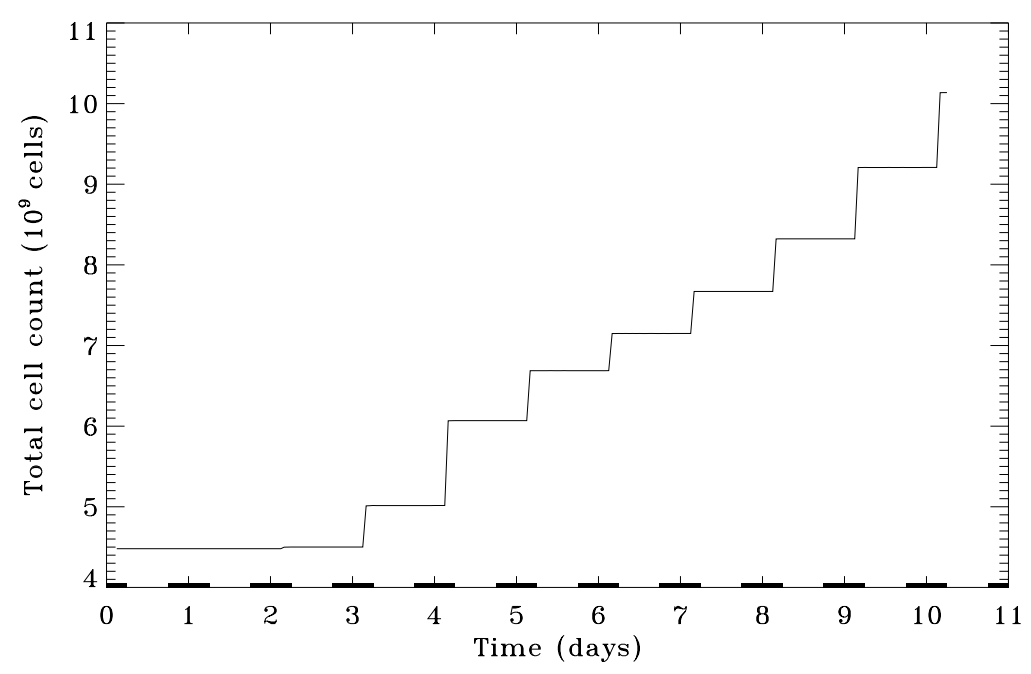

Fig. 8. Least equal daughter reproduction strategy. Simulated population development in the water column over a $10 \mathrm{~d}$ period

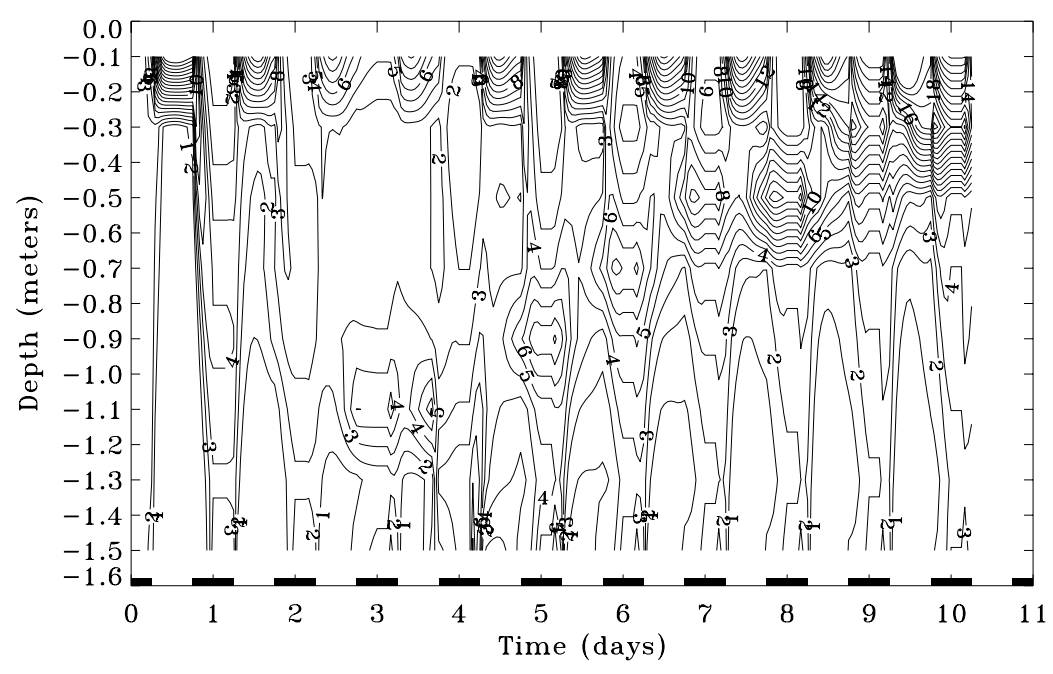

Fig. 9. Least equal daughter reproduction strategy. Simulated vertical cell distribution over a $10 \mathrm{~d}$ period. Units are $10^{6}{\text { cells } \mathrm{l}^{-1}}^{-1}$

dynamics, overcoming the limitation of the classical Eulerian approach.

At the current stage, our model only generically incorporates the metabolisms of the internal cellular carbon and nitrogen as the agents controlling the swimming behavior. More delicate controlling schemes, which look into the details of cellular biochemical composition, can be incorporated into the model in the future. For instance, the metabolisms of carbohydrate, lipid, $\mathrm{NO}_{3}-\mathrm{N}, \mathrm{NH}_{3}-\mathrm{N}$, free amino acid, DNA, RNA, protein, etc., can be considered to be included into the model individually, instead of just the 2 primary elements, cellular carbon and nitrogen. Lipid content is hypothesized to be highly correlated with cells' geotaxis (Kamykowski et al. 1998b). Alternately, aspects of the coherent biochemical models like Geider et al. $(1996,1998)$ or Flynn et al. (1997) may be incorporated.

The hypotheses on the swimming orientation control and swimming speed acclimation proposed in our model can be applied to field populations and field environmental conditions, making the model easy to modify to simulate the field population dynamics under realistic environmental conditions, such as nutrient deplete conditions and the presence of the thermocline, pycnocline, and nutricline. Field PAR intensities at the surface are much higher than the PAR intensity in the Kamykowski et al. (1998b) and Heil (1986) laboratory experiments and vary with time during the day, but this can be readily incorporated into the model. However, data on photosynthesis at PAR levels higher than thus far utilized will be necessary to apply the model in higher light regimes.

Our model will be modified to investigate the red tide dynamics. Gymnodinium breve is common in the Gulf of Mexico at background cell concentrations of $<1 \times 10^{3}$ cells l $^{-1}$ (Geesey \& Tester 1993). In weeks, it can develop into a bloom of fish-killing concen-

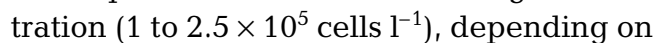
the environmental conditions (e.g. Steidinger 1973, 1975, Steidinger \& Haddad 1981, Tester \& Steidinger 1997). At $10^{5}$ cells $\mathrm{l}^{-1}$ in surface waters, chlorophyll can be detected by satellite sensors, but it isn't until $1 \times$ $10^{6}$ cells $\mathrm{l}^{-1}$ that the human eye can detect discolored surface water. Cell concentrations have been recorded as high as $1 \times$ $10^{7}$ cells $\mathrm{l}^{-1}$ in Florida water (Tester \& Steidinger 1997). The highest surface cell concentration in our present model, reaching at least $9.48 \times 10^{6}$ cells $^{-1}$ during the $3 \mathrm{~d}$ simulation, is a very significant bloom concentration.

Clearly, more observational data, both experimental and field, are required to verify the hypotheses proposed in our model, to further tune the model parameters, and to develop the model to simulate complex field population dynamics under in situ external environmental conditions.

Acknowledgements. We thank Gary Kirkpatrick, Robert E. Reed, and Edward J. Milligan for valuable comments and technical support. This work was supported by ECOHAB: Florida grant funded by the Florida Department of Environmental Protection, NSF grant OCE-95-03253, and NASA grant NAG56586. 
Appendix 1. Swimming behavior

Current research on Gymnodinium breve focuses on its red tide events on the west Florida shelf. The temperature range experienced by $G$. breve in that region is small, mostly mid-20s to lower $30 \mathrm{~s}\left({ }^{\circ} \mathrm{C}\right)$. The variation of the swimming speed responding to temperature change within this range for Gyrodinium dorsum, according to Kamykowski et al. (1988)'s formula, is less than $10 \%$. A cell with an equivalent spherical diameter of $20 \mu \mathrm{m}$, such as G. breve, sinks at a rate of only about $1 \mathrm{~m} \mathrm{~d}^{-1}$ (Kamykowski et al., 1992). Thus, both the temperature acclimation of the swimming speed and the sinking velocity due to buoyancy are neglected in our model. The light acclimation of the swimming speed is significant due to the daily cycle of the solar irradiation and the attenuation of PAR through the water column. Finally, the light-acclimated swimming speed $\left(S_{\text {accli, }}\right.$ in units of $\mathrm{m}$ $\mathrm{h}^{-1}$ ) simplified from the Kamykowski et al. (1988) model is

$$
\begin{aligned}
S_{\text {accli }}= & S_{250} \cdot\left(1+d \cdot\left\{\tanh \left[\alpha \cdot I /\left(d \cdot S_{250}\right)\right]\right.\right. \\
& \left.\left.-\tanh \left[\alpha \cdot 250 \mu \mathrm{E} \mathrm{m}^{-2} \mathrm{~s}^{-1} /\left(d \cdot S_{250}\right)\right]\right\}\right)
\end{aligned}
$$

In the equation, $S_{250}$ is the asymptotic swimming speed acclimated to a light intensity of $250 \mu \mathrm{mol}$ quanta $\mathrm{m}^{-2} \mathrm{~s}^{-1}$ under the experimental conditions (Kamykowski et al. 1988) and the value of $1 \mathrm{~m} \mathrm{~h}^{-1}$ (Heil 1986) (i.e., $278 \mu \mathrm{m} \mathrm{s}^{-1}$, which is used in the argument of hyperbolic tangent) is used for $G$. breve; $\alpha$ is the initial slope of the curve of light acclimated swimming speed increment with the value of $0.55 \mu \mathrm{m} \mathrm{m}^{2} \mu \mathrm{mol}$ quanta ${ }^{-1}$; a $d$ of 0.26 is the observed factor for Gyrodinium dorsum (Kamykowski et al. 1988) which is used for G. breve in our model; and $I$ is the PAR intensity, which is zero at night.

In our model, both the swimming orientation and speed are hypothesized to be influenced by and to acclimate to the internal cellular biochemical and physiological states, external environmental conditions, and certain endogenous circadian rhythms. The characteristics of the hypothesized influences vary between different time periods during the diel cycle. Swimming orientation controls for the light period and the dark period are different. The dark controlling period is further separated into 3 subperiods: before midnight, after midnight but before 04:00 h, and a $2 \mathrm{~h}$ period between 04:00 and 06:00 $\mathrm{h}$ (the time of lights-on), as the control of endogenous circadian rhythms. Note that some of the hypotheses on the swimming orientation control and swimming speed acclimation proposed in our model bear the field population and in situ external environmental conditions in mind. Logical reasoning is used to construct most of the swimming speed acclimation formulas below based on the laboratory observations. Note that all the swimming controlling rules discussed below apply to all the cells in the population, no matter whether the cells are poor cells or rich cells.

During the light period, photosynthesis holds the highest priority. The ascending swimming velocity during the light period is given as:

$$
V_{z}=S_{\text {accli }}\left(\frac{C n_{\max }-C n}{C n_{\max }-C n_{\min }}\right)^{2}
$$

This acclimation allows cells with lower internal carbon content to ascend faster. A cell ascends or stays (for those that have already reached the surface) at the surface until its internal carbon pool fills to certain high levels or until its cumulative photoinhibition goes above a certain threshold $\left(H_{\mathrm{csw}}\right)$, which will be discussed below.
We note that in our model the index for $z, j_{z}$ increases downwards so that the displacements along the increasing $j_{z}$ axis in Eq. (10) have a sign opposite to the velocities given in Eqs. (A2)-(A7), e.g., a negative velocity corresponds to a positive displacement in the $j_{z}$ direction. $V_{z}$ in Eqs. (A2)-(A7) has the same meaning as $V_{z}$ in Eqs. (3), (6), (8) \& (9).

In the case where the cumulative photoinhibition of a cell exceeds the threshold, $H_{\text {csw }}$, which is set at 0.8 out of 1.0 in our model, the cell descends to avoid a high intensity of PAR. The magnitude of this descending velocity is simply the light acclimated swimming speed given by Eq. (A1),

$$
V_{z}=-S_{\text {accli }}
$$

The light intensity decreases with depth; thus the descending cell's cumulative photoinhibition may decrease with time. If its cumulative photoinhibition reduces below the threshold during the light period, the cell may ascend again if other swimming orientation controlling factors allow.

Two internal cellular carbon thresholds are considered in our model for swimming orientation control during the light period. The higher cellular carbon threshold, $C n_{\text {Full, }}$ is set at $87.3 \mathrm{pmol} \mathrm{C} \mathrm{cell}^{-1}$, which is at $95 \%$ of the range. Any cells whose internal carbon is above this level are considered to have filled their carbon pool and descend, because this amount of carbon is above the internal cellular carbon threshold for cell division (see 'Cell reproduction strategy'). These cells can continue to fill their carbon pool up to $100 \%$ full if, as they descend, they are exposed to sufficient PAR, which is the case in our simulations. These descending high-carbon cells may downgrade by losing their internal carbon to protein synthesis if they descend into depths with insufficient PAR intensity and change the orientation to upward direction again during the light period. This descending velocity is specified as

$$
V_{z}=-S_{\text {accli }}\left[0.2+0.8\left(1-\frac{\left[N O_{3}(z)\right]}{K_{N}+\left[N O_{3}(z)\right]}\right)\right]\left(\frac{C n-C n_{\text {High }}}{C n_{\max }-C n_{\text {High }}}\right)^{\frac{1}{2}}
$$

Because the priority for these descending cells changes to nitrogen uptake, this descending swimming speed is acclimated to the external nitrogen conditions. The higher the surrounding external nitrogen concentration, the slower the descending speed. The cells which have more internal cellular carbon descend faster because they have less demand for PAR for further photosynthesis.

According to the observation that the internal cellular carbon is higher at the mid-column than at the surface (Kamykowski et al. 1998b), a lower carbon threshold, $C n_{\text {High }}$ is set at $68.4 \mathrm{pmol} \mathrm{C}$ cell $^{-1}$, which is at $60 \%$ of the range. The swimming orientation of the cells having internal carbon between $C n_{\text {High }}$ and $C n_{\text {Full }}$ is controlled by a different set of rules. The internal carbon content of these cells is high but not high enough for cell division, so they still have the priority to build their internal carbon. Gymnodinium breve is a dinoflagellate species capable of having high photosynthetic capacity at low light and adapting to varying light environments (Shanley 1985, Garcia \& Purdie 1992), so we assume there may be a common low PAR threshold which most $G$. breve cells may be comfortable with no matter if these $G$. breve cells are currently low-light adapted or high-light adapted. Hence, a PAR threshold, $I_{\text {th }}$ is introduced for these cells. This PAR threshold in our model is set at $17.5 \mu \mathrm{mol}$ quanta $\mathrm{m}^{-2} \mathrm{~s}^{-1}$ (equal to $5 \%$ of the 
Appendix 1 (continued)

constant $350 \mu$ mol quanta $\mathrm{m}^{-2} \mathrm{~s}^{-1} \mathrm{PAR}$ at the surface in the Kamykowski et al. [1998b] experiment) and is within the range of the low-light adapted sun-shade acclimated saturation PAR intensity, $I_{k \prime}$, which was discussed earlier. Among these cells, those exposed to lower PAR intensities than the threshold continue to ascend until the PAR intensity exposure equals the PAR threshold, while those located at the depths exposed to higher PAR intensities descend until the depth with the threshold PAR intensity is reached, unless they have both their internal carbon pools below $80 \%$ of the range and their internal nitrogen pools above $90 \%$ of the range. These cells with both high internal nitrogen and relatively low internal carbon delay descent and stay at their current depths for higher PAR intensities than the threshold PAR intensity. The acclimated descending velocity for the cells in this category is also determined by Eq. (A4).

The ascending or descending cells are bounded by the surface and the bottom of the water column, respectively, and will be trapped at the boundaries until their swimming directions change.

During the dark period, nitrogen uptake holds the highest priority. Between sunset and midnight, cells descend with velocity

$$
\begin{aligned}
V_{z}= & -S_{\text {accli }}\left[0.2+0.8\left(1-\frac{\left[N O_{3}(z)\right]}{K_{N}+\left[N O_{3}(z)\right]}\right)\right] \\
& \times\left(0.515\left\{1+\tanh \left[12-13.33\left(\frac{N-N_{\min }}{N_{\max }-N_{\min }}\right)\right]\right\}-0.069\right)
\end{aligned}
$$

The external nitrogen concentration at a cell's location again controls the cell's descending speed. Cells having lower internal nitrogen content descend faster, and the cells having full internal nitrogen pool barely descend at all, because they have no demand for nitrogen uptake.
After midnight, all the cells stop descending and stay at the depths where they are located unless the external nitrogen concentrations at their depth is lower than a threshold which makes cells' nitrogen uptake rates reach $75 \%$ of the potential maximum rate:

$$
\frac{\left[\mathrm{NO}_{3}\right]_{\mathrm{th}}}{K_{\mathrm{N}}+\left[\mathrm{NO}_{3}\right]_{\mathrm{th}}}=0.75 \quad \text { or } \quad\left[\mathrm{NO}_{3}\right]_{\mathrm{th}}=3.0 K_{N}
$$

For the $K_{n}$ of $0.42 \mu \mathrm{M} \mathrm{NO}-\mathrm{N}$ in our simulation, $\left[\mathrm{NO}_{3}\right]_{\text {th }}$ is $1.26 \mu \mathrm{M} \mathrm{NO}-\mathrm{N}$. Cells which are exposed to external nitrogen concentrations lower than the threshold continue to descend with the descending speed specified by Eq. (A5) until they find the depth with the appropriate external nitrogen concentration and stay there or until the time, which is set at 04:00 $\mathrm{h}$ (i.e., $2 \mathrm{~h}$ prior to lights-on), runs out. These controlling mechanisms may have important biological meaning for field populations because they prevent unnecessary descent during the night under adequate external nutrient conditions so that the cells can expeditiously ascend towards PAR intensities adequate for photosynthesis the next day. Hence the period between midnight and 04:00 $\mathrm{h}$ is named 'the resting period' in our model.

During the $2 \mathrm{~h}$ period prior to lights-on, any cells whose internal nitrogen contents are more than $90 \%$ of the range (nitrogen-rich) or internal carbon contents are less than $10 \%$ of the range (carbon-poor) ascend in anticipation of the next light period for the next cycle of the photosynthesis. Other cells stay where they are. The ascending velocity during this period is

$$
V_{z}=0.25 S_{\text {accli }}\left(\frac{C n_{\max }-C n}{C n_{\max }-C n_{\min }}\right)
$$

After 06:00 h (lights-on), the next cycle begins.

\section{LITERATURE CITED}

Blasco D (1978) Observations on diel migration of marine dinoflagellates off the Baja California coast. Mar Biol 46: 41-47

Chisholm SW, Vaulot D, Olsen RJ (1984) Cell cycle controls in phytoplankton. In: Edmunds LN Jr (ed) Cell cycle clocks. M Dekker, New York, p 365-394

Cullen JJ (1985) Diel vertical migration by dinoflagellates: roles of carbohydrate metabolism and behavioral flexibility. In: Rankin MA (ed) Migration: mechanism and adaptive significance. Cont Mar Sci 27:135-152

Cullen JJ, Horrigan SG (1981) Effects of nitrate on the diurnal vertical migration, carbon to nitrogen ratio, and the photosynthetic capacity of the dinoflagellate, Gymnodinium splendens. Mar Biol 62:81-89

Cullen JJ, Zhu M, Davis RF, Peterson DC (1985) Vertical migration, carbohydrate synthesis and nocturnal uptake during growth of Heterocapsa niei in a laboratory column. In: Anderson DM, White AW, Baden DG (eds) Toxic dinoflagellates. Elsevier, New York, p 189-194

Denman KL, Gargett AE (1995) Biological-physical interactions in the upper ocean: the role of vertical and small scale transport processes. Annu Rev Fluid Mech 27:225-255

Denman KL, Marra J (1986) Modelling the time dependent photoadaptation of phytoplankton to fluctuating light. In:
Nihoul JCJ (ed) Marine interfaces ecohydrodynamics. Elsevier, Amsterdam, p 341-349

DiTullio GR (1993) Incorporation of ${ }^{14} \mathrm{CO}_{2}$ into protein as an estimate of phytoplankton $\mathrm{N}$-assimilation and relative growth rate. In: Kemp PF, Sherr BF, Sherr EB, Cole JJ (eds) Handbook of methods in aquatic microbial ecology. Lewis Publishers, London, p 573-578

Dortch Q, Clayton JR, Thoresen SS, Ahmed SI (1984) Species differences in accumulation of nitrogen pools in phytoplankton. Mar Biol 81:237-250

Eppley RW, Harrison WG (1979) Physiological ecology of Gonyaulax polyedra, a red water dinoflagellate off southern California. In: Taylor DL, Seliger HH (eds) Toxic dinoflagellate blooms. Proc 1st Int Conf Mass Sci Technol Found, p 11-22

Eppley RW, Holm-Hansen O, Strickland JDH (1968) Some observations on the vertical migration of dinoflagellates. J Phycol 4:333-340

Flynn KJ, Flynn K (1998) Release of nitrite by marine dinoflagellates: development of a mathematical simulation. J Plankton Res 130:455-470

Flynn KJ, Flynn K, John EH, Reguera B, Reyero MI, Franco JM (1996) Changes in toxins, intracellular and dissolved free amino acids of the toxic dinoflagellate Gymnodinium catenatum in response to changes in inorganic nutrients and salinity. J Plankton Res 18:2093-2111 
Flynn KJ, Michael JR, Fasham JR, Hipkin CR (1997) Modelling the interactions between ammonium and nitrate uptake in marine phytoplankton. Philos Trans R Soc Lond B 352:1625-1645

Forward RB (1970) Change in the photoresponse action spectrum of the dinoflagellate Gyrodinium dorsum Kofoid by red and far-red light. Planta (Berl) 92:245-258

Forward RB (1973) Phototaxis in a dinoflagellate: action spectra as evidence for a 2 pigment system. Planta (Berl) 11: 167-178

Forward RB (1974) Phototaxis in the dinoflagellate Gymnodinium splenders Lebour. J Protozool 21:312-315

Forward RB, Davenport D (1968) Red and far-red light effects on short-term behavioral response of a dinoflagellate. Science 161:1028-1029

Forward RB, Davenport D (1970) The circadian rhythm of a behavioral photoresponse in the dinoflagellate Gyrodinium dorsum. Planta (Berl) 92:259-266

Garcia VMT, Purdie DA (1992) The influence of irradiance on growth, photosynthesis and respiration of Gymnodinium cf. aureolum. J Plankton Res 14:1251-1256

Geesey M, Tester P (1993) Gymnodinium breve: ubiquitous in Gulf of Mexico waters? In: Smayda TJ, Shimizu Y (eds) Toxic phytoplankton blooms in the sea. Elsevier, Amsterdam, p 251-255

Geider RJ, MacIntyre HL, Kana TM (1996) A dynamic model of photoadaptation in phytoplankton. Limnol Oceanogr 41:1-15

Geider RJ, MacIntyre HL, Kana TM (1998) A dynamic regulatory model of phytoplanktonic acclimation to light, nutrients, and temperature. Limnol Oceanogr 43:679-694

Harris GP, Heaney SI, Talling JF (1979) Physiological and environmental constraints in the ecology of the planktonic dinoflagellate Ceratium hirudinella. Freshw Biol 9:413-428

Harrison WG (1976) Nitrate metabolism of the red tide dinoflagellate Gonyaulax polyedra Stein. J Exp Mar Biol Ecol 21:199-209

Heaney SI, Eppley RW (1981) Light, temperature and nitrogen as interacting factors affecting diel vertical migrations of marine dinoflagellates. J Plankton Res 3:331-344

Heaney SI, Furness TI (1980) Laboratory models of diel vertical migration of marine dinoflagellates. Mar Biol 62:57-64

Heaney SI, Talling JF (1980) Dynamic aspects of dinoflagellate distribution patterns in a small productive lake. J Ecol 68:75-94

Heil C (1986) Vertical migration of Ptychodiscus breve (Davis) Steidinger. MS thesis, University of South Florida, St. Petersburg

Holmes RW, Williams PM, Eppley RW (1967) Red water in La Jolla Bay, 1964-1966. Limnol Oceanogr 12:503-512

Janowitz GS, Kamykowski D (1991) An Eulerian model of phytoplankton photosynthetic response in the upper mixed layer. J Plankton Res 13:983-1002

Janowitz GS, Kamykowski D (1999) An expanded Eulerian model of phytoplankton environmental response. Ecol Model 118:237-247

Kamykowski D (1981) Laboratory experiments on the diurnal vertical migration of marine dinoflagellates through temperature gradients. Mar Biol 62:57-64

Kamykowski D (1995) Trajectories of autotrophic marine dinoflagellates. J Phycol 31:200-208

Kamykowski D, McCollum SA (1986) The temperature acclimatized swimming speed of selected marine dinoflagellates. J Plankton Res 8:275-287

Kamykowski D, Yamazaki H (1997) A study of metabolisminfluenced orientation in the diel vertical migration of marine dinoflagellates. Limnol Oceanogr 42:1189-1202
Kamykowski D, Zentara SJ (1977) The diurnal vertical migration of phytoplankton through temperature gradients. Limnol Oceanogr 22:148-151

Kamykowski D, McCollum SA, Kirkpatrick GJ (1988) Observations and a model concerning the translational velocity of a photosynthetic marine dinoflagellate under variable environmental conditions. Limnol Oceanogr 33:66-78

Kamykowski D, Reed RE, Kirkpatrick GJ (1992) Comparison of sinking velocity, swimming velocity, rotation and path characteristics among six marine dinoflagellate species. Mar Biol 113:319-328

Kamykowski D, Yamazaki H, Yamazaki AK, Kirkpatrick GJ (1998a) A comparison of how different orientation behaviors influence dinoflagellate trajectories and photoresponses in turbulent water columns. In: Anderson DM, Cembella AD, Hallegraeff GM (eds) Physiological ecology of harmful algal blooms. Springer-Verlag, Berlin, p 581-599

Kamykowski D, Milligan EJ, Reed RE (1998b) Biochemical relationships with the orientation of the autotrophic dinoflagellate Gymnodinium breve under nutrient-saturated conditions. Mar Ecol Prog Ser 167:105-117

Kamykowski D, Milligan EJ, Reed RE (1998c) Relationship between geotaxis/phototaxis and diel vertical migration in autotrophic dinoflagellates. J Plankton Res 20:1781-1796

Kirkpatrick GJ, Kamykowski D, Reed RE (1997) Phytoplankton quantum yield measured on minute time scales in situ. In: AcKleson SG, Frouin R (eds) Ocean optics XIII. Proc. SPIE 2963:868-873

Lande R, Lewis M (1989) Models of photoadaptation and photosynthesis by algal cells in a turbulent mixed layer. DeepSea Res 36:1161-1175

Lebert M, Hader DP (1996) How Euglena tells up and down. Nature 379:590

Levandowsky M, Kaneta P (1987) Behavior in dinoflagellates. In: Taylor FJR (ed) The biology of dinoflagellates. Blackwell Scientific, Oxford, p 360-397

Liu G (2000) A numerical study of the population dynamics of the autotrophic dinoflagellate Gymnodinium breve. PhD dissertation, North Carolina State University, Raleigh

MacIntyre JG, Cullen JJ, Cembella AD (1997) Vertical migration, nutrition and toxicity in the dinoflagellate Alexandrium tamarense. Mar Ecol Prog Ser 148:201-216

Odum HT, Lackey JB, Hynes J, Marshall N (1955) Some red tide characteristics during 1952-1954. Bull Mar Sci Gulf Caribb 5:247-258

Passow U (1991) Vertical migration of Gonyaulax catenata and Mesodinium rubrum. Mar Biol 110:455-463

Raven JA (1983) Dinophyte flagella: a cost-benefit analysis. Br Phycol J 18:208

Riley GA (1956) Oceanography of Long Island Sound, 1952-54. II. Physical oceanography. Bull Bingham Oceanogr Coll 15:15-46

Shanley E (1985) Photoadaptation in the red tide dinoflagellate Ptychodiscus brevis. MS thesis, University of South Florida, St. Petersburg

Shanley E, Vargo GA (1993) Cellular composition, growth, photosynthesis, and respiration rates of Gymnodinium breve under varying light levels, In: Smayda TJ, Shimizu $\mathrm{Y}$ (eds) Toxic phytoplankton blooms in the sea. Elsevier, New York, p 831-836

Sibley TH, Herrgesell PL, Knight AW (1974) Density-dependent vertical migration in the freshwater dinoflagellate Peridnium penardii (Lemm.) Lemm. fo. Californicum Javorn. J Phycol 10:475-476

Steidinger KA (1973) Phytoplankton ecology: a conceptual review based on eastern Gulf of Mexico research. CRC Crit Rev Microbiol 3:49-67 
Steidinger KA (1975) Implications of dinoflagellate life cycles on initiation of Gymnodinium breve red tides. Environ Lett 9:129-139

Steidinger KA, Haddad K (1981) Biological and hydrographic aspects of red tides. BioScience 31:814-819

Steidinger KA, Ingle RM (1972) Observations on the 1971 summer red tide in Tampa Bay. Fla Environ Lett 3: 271-278

Steidinger KA, Joyce EA (1973) Florida red tides. Fla Dept Nat Res Mar Res Lab Educ Ser No. 17:1-26

Steidinger KA, Vargo GA, Tester PA, Tomas CR (1998) Bloom dynamics and physiology of Gymnodimium breve with emphasis on the Gulf of Mexico. In: Anderson DM, Cembella AD, Hallegraeff GM (eds) Physiological ecology of harmful algal blooms. Springer-Verlag, Berlin, p 133-153

Editorial responsibility: Evelyn and Barry Sherr (Contributing Editors), Corvalis, Oregon, USA
Tester PA, Steidinger KA (1997) Gymnodinium breve red tide blooms: initiation, transport, and consequences of surface circulation. Limnol Oceanogr 42:1039-1051

Tyler MA, Seliger HH (1981) Selection for a red tide organism: physiological responses to the physical environment. Limnol Oceanogr 26:310-324

Weiler CS, Karl DM (1979) Diel changes in phase-division culture of Ceratium furca (Dinophyceae): nucleotide triphosphate, denylate energy charge, cell carbon and patterns of vertical migration. J Phycol 15:384-391

Woods JD, Onken R (1982) Diurnal variation and primary production in the ocean-preliminary results of a Lagrangian ensemble model. J Plankton Res 4:735-756

Yamasaki AK, Kamykowski D (2000) A biophysical model of population dynamics of the autotrophic dinoflagellate Gymnodimium breve. Ecol Model 134:59-72

Submitted: October 7, 1999; Accepted: May 18, 2000

Proofs received from author(s): January 2, 2001 